\title{
Effect of starvation on global gene expression and proteolysis in rainbow trout (Oncorhynchus mykiss) Mohamed Salem ${ }^{1}$, Jeff Silverstein ${ }^{2}$, Caird E Rexroad III $^{2}$ and Jianbo Yao*1
}

Address: ${ }^{1}$ Laboratory of Animal Biotechnology and Genomics, Division of Animal and Nutritional Sciences, West Virginia University, Morgantown, WV 26505, USA and ${ }^{2}$ U.S. Department of Agriculture, Agricultural Research Service, National Center for Cool and Cold Water Aquaculture, Kearneysville, WV 25430, USA

Email: Mohamed Salem - mohamed.salem@mail.wvu.edu; Jeff Silverstein - Jeff.Silverstein@ARS.USDA.GOV; Caird E Rexroad - crexroad@ncccwa.ars.usda.gov; Jianbo Yao* - jianbo.yao@mail.wvu.edu

* Corresponding author

Published: 19 September 2007

BMC Genomics 2007, 8:328 doi:10.1/86/147|-2164-8-328
Received: 7 February 2007

Accepted: 19 September 2007

This article is available from: http://www.biomedcentral.com/I47I-2I64/8/328

(C) 2007 Salem et al; licensee BioMed Central Ltd.

This is an Open Access article distributed under the terms of the Creative Commons Attribution License (http://creativecommons.org/licenses/by/2.0), which permits unrestricted use, distribution, and reproduction in any medium, provided the original work is properly cited.

\begin{abstract}
Background: Fast, efficiently growing animals have increased protein synthesis and/or reduced protein degradation relative to slow, inefficiently growing animals. Consequently, minimizing the energetic cost of protein turnover is a strategic goal for enhancing animal growth. Characterization of gene expression profiles associated with protein turnover would allow us to identify genes that could potentially be used as molecular biomarkers to select for germplasm with improved protein accretion.
\end{abstract}

Results: We evaluated changes in hepatic global gene expression in response to 3-week starvation in rainbow trout (Oncorhynchus mykiss). Microarray analysis revealed a coordinated, downregulated expression of protein biosynthesis genes in starved fish. In addition, the expression of genes involved in lipid metabolism/transport, aerobic respiration, blood functions and immune response were decreased in response to starvation. However, the microarray approach did not show a significant increase of gene expression in protein catabolic pathways. Further studies, using real-time PCR and enzyme activity assays, were performed to investigate the expression of genes involved in the major proteolytic pathways including calpains, the multi-catalytic proteasome and cathepsins. Starvation reduced mRNA expression of the calpain inhibitor, calpastatin long isoform (CAST-L), with a subsequent increase in the calpain catalytic activity. In addition, starvation caused a slight but significant increase in 20S proteasome activity without affecting mRNA levels of the proteasome genes. Neither the mRNA levels nor the activities of cathepsin $D$ and $L$ were affected by starvation.

Conclusion: These results suggest a significant role of calpain and 20S proteasome pathways in protein mobilization as a source of energy during fasting and a potential association of the CAST$\mathrm{L}$ gene with fish protein accretion.

\section{Background}

Protein turnover is a major determinant in the conversion of feed into growth [1]. Young and others [2] reported that $15 \%$ to $25 \%$ of the energy consumed by growing animals is used for protein breakdown and re-synthesis. Consequently, minimizing the energetic cost of protein 
turnover is a strategic goal for enhancing animal growth and feed efficiencies.

Protein accretion is the net effect of protein synthesis and degradation. When protein synthesis rates are similar, factors affecting protein degradation are critical in explaining differences in growth efficiency of individuals $[1,3]$. Recently, we showed that fish muscle protein degradation depends on activities of proteolytic enzymes that are tightly controlled and regulated [4-7]. The major systems involved in fish muscle proteolysis are 1) membranebound lysosomal enzymes, 2) ubiquitin-proteasome pathway enzymes, and 3) calcium-dependent calpain proteinases.

Fish swiftly use proteins as oxidative substrates [8] and proteins have traditionally been considered to be the usual gluconeogenic precursors during starvation in fish [9]. Rates of protein synthesis also fall during starvation $[10,11]$. The primary objective of this study was to use microarray technology to identify genes/pathways involved in starvation-related protein turnover. These genes could potentially be used as molecular biomarkers to study protein turnover and select for germplasm with improved protein accretion in rainbow trout (Oncorhynchus mykiss).

Salmonids during their life cycle may face extended periods without food. Fish during starvation depends on body energy reserves. An effective way to identify the relationships between major metabolic pathways and body processes is to examine changes in metabolism during starvation. The secondary objective of this study was to use microarray to identify metabolic adaptations of liver tissue during starvation in rainbow trout.

Our microarray experiments showed a synchronized down-regulated expression of protein biosynthesis genes in starved fish but no significant changes of gene expression in the major protein catabolic pathways were observed. To further investigate the effect of starvation on protein degradation, we used real-time PCR and enzyme activity assays (more sensitive and accurate methods) to measure the expression of genes and enzyme activities in the major proteolytic systems. Our results suggest a significant role of calpain and 20S proteasome pathways in rainbow trout protein turnover under fasting condition.

\section{Results and discussion}

We performed microarray experiments to evaluate the changes in hepatic gene expression in response to starvation in rainbow trout. Microarray analysis defined 202 down-regulated and 27 up-regulated unique transcripts in starved fish $( \pm 1.5$-fold change, $\mathrm{P}<0.05)$. Expression of 5 randomly selected genes, identified by microarray as dif- ferentially expressed, was confirmed by quantitative real time PCR analysis (Fig. 1, p < 0.05), indicating the reliability of the microarray data. The expression trends of all 5 genes were similar in both microarray and real-time PCR analyses. The differentially expressed genes were classified according to the GO biological functions (Fig. 2).

\section{Protein biosynthesis}

Our microarray data showed that $28 \%$ of the differentially expressed genes belong to the protein biosynthesis machinery (Fig. 2). Almost all the protein biosynthesis genes were down-regulated (Table 1). The list includes 47 cytoplasmic ribosomal protein genes (30 for large subunit and 17 for small subunit) and 5 mitochondrial ribosomal protein genes ( 2 for large subunit and 3 for small subunit). Ribosomal proteins are essential for mRNA translation into protein [12], and they are integral components of the ribosome. Ribosomal proteins stabilize the rRNA structure and regulate translocation of mRNA and tRNA, which is necessary for optimal translation [13]. The downregulated expression of the ribosomal proteins in starved fish suggests a well-regulated decrease in rate of protein synthesis at transcription. Control of gene expression at transcription would allow rapid suppression of protein biosynthesis when amino acids are deficient.

Starved fish exhibited up-regulated expression of eukaryotic translation initiation factor $2 \mathrm{C}, 1$, and S2, Translation initiation factors are essential for protein synthesis [14]. A

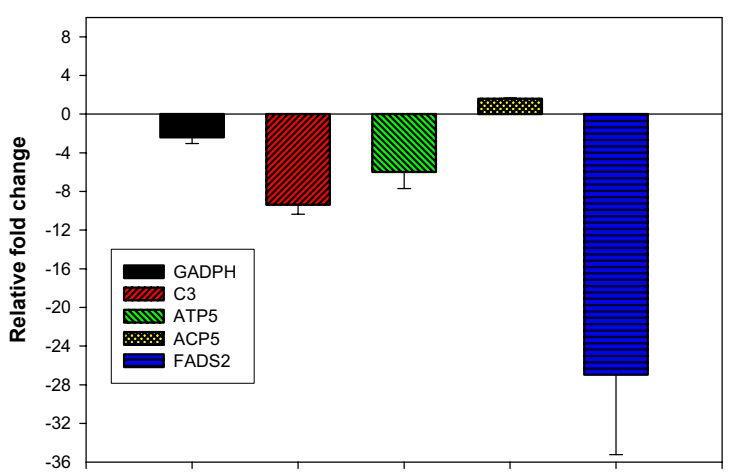

\section{Figure I}

Quantitative real-time PCR confirmation of differential expression for 5 randomly selected genes identified by microarray as differentially expressed (Means \pm S.E., $n=6, P$ $<0.05$ ). The expression trends for all 5 genes were similar in both microarray and real-time PCR analyses. The average fold changes detected by microarray for GADPH, C3, ATP5, ACP5 and FADS2 were -2.9, -2.7, -5.0, 5.7, and -9.5, respectively. 


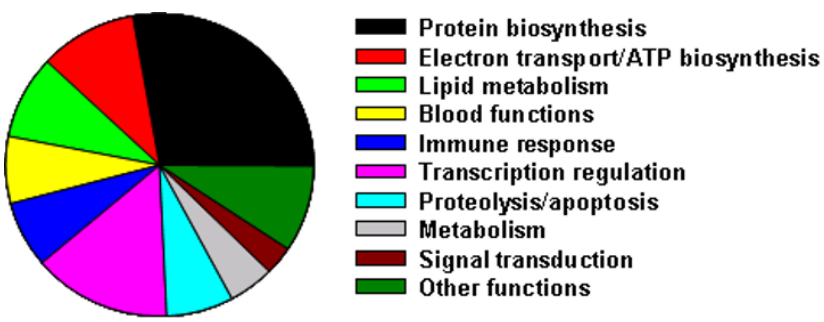

Figure 2

Summary of differentially expressed genes that have significant tBLASTX identity with genes assigned to $\mathrm{GO}$ biological function categories.

similar eukaryotic translation initiation factor $(\mathrm{eIF} 2 \alpha)$ is a highly conserved adaptor to stress [15]. The upregulated expression of the eukaryotic translation initiation factors may be to keep the basal level of protein translation or as a consequence of starvation stress. On the other hand, the eukaryotic translation elongation factors 1 alpha, EEF1A1, and beta, EEF1B2, were down-regulated. Jurss and coworkers [16] reported that rainbow trout in vitro protein synthesis-stimulating activity is reduced by food deprivation and can be compensated by addition of elongation factors EF1 and/or EF2. Consequently, availability of eukaryotic translation factors, EF1 and EF2, may be a ratedetermining point for rainbow trout protein synthesis. In addition, the biotinidase transcript, which catalyzes the release of biotin from biocytin, was also down regulated in starved fish. Theoretically, formation of translation initiation complexes may depend on biotin [17]. Expression of the peptidyl-prolyl, cis-trans, isomerase A (Cyclophilin A) declined in starved fish. This enzyme is ubiquitous and encodes essential step in protein folding and post-translational modification. In addition, the beta subunit of Sec61 protein, which is involved in the co-translational protein transport system [18], was down-regulated in starved fish suggesting impaired intracellular protein transport.

Tripathi and Verma [11] reported a reduction in an overall capacity for protein synthesis in starved catfish. Peragon and colleagues [9] found that, during starvation, total hepatic-protein and RNA contents decreased significantly, and the absolute protein-synthesis rate also fell. Pace and Manahan [19] reported that protein synthesis accounted for $16 \pm 4 \%$ and $75 \pm 11 \%$ of metabolism in unfed and fed sea urchin larvae, respectively. Protein synthesis accounts for a high percentage of the individual's metabolic costs. Consequently, regulation of protein synthesis is a promising means to limit energy expenditures under unfavorable feeding condition. These reports are consistent with our results showing highly regulated protein synthesis rates in fish liver in response to starvation. Less essential pathways such as protein synthesis are reduced to minimize ATP demands $[20,21]$.

\section{Mitochondrial functions and glucose metabolism}

Several genes belonging to complexes of the mitochondrial electron transport pathway were down-regulated. These genes include complex III (Ubiquinol-cytochrome c oxidoreductases), complex IV (Cytochrome c oxidase) and complex V ATP synthase (Table 2). In addition, succinyl-CoA synthetase alpha subunit of the citric acid cycle was down-regulated in starved fish. Furthermore, several members of the adenine nucleotide translocator that transports ATP out of the mitochondrion matrix in exchange for ADP produced in the cytosol were down-regulated. Similarly, a mitochondrial phosphate carrier, which returns phosphate generated by ATP breakdown to the mitochondrion, was down-regulated. An outer mitochondrial membrane translocase, TOMM7, which mediates the translocation of preproteins into or across the outer mitochondrial membrane, was down-regulated in starved fish. Conversely, TOMM40 was up-regulated. The vast majority of mitochondrial proteins are synthesized from nuclear DNA as precursor proteins on cytosolic polysomes, and these proteins must be imported into the mitochondria [22]. Our results point to impaired mitochondrial functions and an overall reduction in ATP production capacity as a result of starvation. Maintenance of high metabolic rates following the exhaustion of energy reserves during starvation would compromise animals' ability to survive [23].

On the other hand, energy production through anaerobic mechanisms seems to be less sensitive than aerobic (mitochondrial) mechanisms in responding to an inadequate supply of energetic compounds from food sources. Starvation caused a decreased expression of a single glycolytic pathway enzyme; GAPDH. Surprisingly, other members of the glycolytic pathway, including the highly regulated and rate-limiting enzymes, hexokinase, phosphofructokinase and pyruvate kinase were not affected (Table 2). Moreover, expression of ribose 5-phosphate isomerase A, a member of the pentose phosphate pathway that is responsible for $30 \%$ of the hepatic glucose oxidation [14], was up-regulated in starved fish. The lack of a coordinated, down-regulated expression of the glycolytic pathway enzymes upon starvation support the notion of altered regulation for carbohydrate metabolism in carnivorous fish such as rainbow trout as compared to mammals $[23,24]$. To explain the low dietary glucose utilization in rainbow trout, Wilson [24] hypothesized the existence of dysfunctional regulation of hepatic glycolysis and gluconeogenesis. No dietary requirement for carbohydrate has been demonstrated in fish. When carbohydrates are not provided in the diet, other nutrients 
Table I: Differentially expressed genes of the protein biosynthesis

\begin{tabular}{|c|c|c|c|c|c|}
\hline Symbol & Gene name & ACC.\# & p value & GO Term & $\begin{array}{c}\text { Fold } \\
\text { change }\end{array}$ \\
\hline Mrpl36 & Mitochondrial ribosomal protein L36 & CB511228 & $7.8 \mathrm{E}-03$ & protein biosynthesis - GO:00064I2 & -4.1 \\
\hline Mrpl44 & Mitochondrial ribosomal protein L44 & CK991088 & $3.6 \mathrm{E}-04$ & protein biosynthesis - GO:00064I2 & -5.8 \\
\hline MRPSI 5 & Mitochondrial ribosomal protein SI5 & CB494646 & $3.6 \mathrm{E}-03$ & protein biosynthesis - GO:00064I2 & -4.1 \\
\hline MRPSI7 & Mitochondrial ribosomal protein SI7 & CB504359 & 7.9E-03 & protein biosynthesis - GO:00064I2 & -3.2 \\
\hline Mrps30 & Mitochondrial ribosomal protein S30 & $\overline{\mathrm{CB} 492525}$ & $1.8 \mathrm{E}-04$ & protein biosynthesis - GO:00064I2 & -5.5 \\
\hline RPLIO & Ribosomal protein LIO & CA770456 & 4.7E-03 & protein biosynthesis - GO:00064I2 & -3.3 \\
\hline RPLIOA & Ribosomal protein LIOa & CB49105I & I.3E-03 & protein biosynthesis - GO:00064I2 & -2.4 \\
\hline RpllI & Ribosomal protein LII & CA052515 & $4.5 \mathrm{E}-03$ & protein biosynthesis - GO:00064I2 & -3.7 \\
\hline Rpll2 & Ribosomal protein $\mathrm{LI} 2$ & CA044425 & $2.2 \mathrm{E}-03$ & protein biosynthesis - GO:00064I2 & -3.4 \\
\hline RPLI3A & Ribosomal protein LI $3 \mathrm{a}$ & CA052724 & I.IE-02 & protein biosynthesis - GO:00064I2 & -2.8 \\
\hline RPLI4 & Ribosomal protein LI4 & CB493023 & $3.9 \mathrm{E}-03$ & protein biosynthesis - GO:00064I2 & -4.9 \\
\hline RPLI7 & Ribosomal protein $\mathrm{LI} 7$ & $\overline{\mathrm{CA} 062149}$ & 5.7E-03 & protein biosynthesis - GO:00064I2 & -2.9 \\
\hline RPL2I & Ribosomal protein L2I & $\overline{\mathrm{CA} 044118}$ & $1.0 \mathrm{E}-02$ & protein biosynthesis - GO:00064I2 & -3.5 \\
\hline RPL23 & Ribosomal protein $\mathrm{L} 23$ & $\overline{\mathrm{CA} 061476}$ & $4.9 \mathrm{E}-04$ & protein biosynthesis - GO:00064I2 & -4.5 \\
\hline RPL23A & Ribosomal protein L23a & $\overline{\mathrm{CA} 052583}$ & 4.4E-03 & protein biosynthesis - GO:00064I2 & -3.2 \\
\hline Rpl24 & Ribosomal protein L24 & CA051932 & $1.5 \mathrm{E}-02$ & protein biosynthesis - GO:00064I2 & -2.5 \\
\hline Rpl26 & Ribosomal protein L26 & CB497727 & $3.6 \mathrm{E}-02$ & protein biosynthesis - GO:00064I2 & -3.1 \\
\hline RPL27 & Ribosomal protein $\mathrm{L} 27$ & CA037570 & $1.0 \mathrm{E}-02$ & protein biosynthesis - GO:00064I2 & -5.4 \\
\hline Rpl28 & Ribosomal protein L28 & CB502045 & 4.IE-04 & protein biosynthesis - GO:00064I2 & -5.1 \\
\hline RPL3 & Ribosomal protein L3 & $\overline{\mathrm{CB} 487027}$ & $1.5 \mathrm{E}-02$ & protein biosynthesis - GO:00064I2 & -5.6 \\
\hline Rpl3I & Ribosomal protein L3I & CK990835 & 5.7E-05 & protein biosynthesis - GO:00064I2 & -4.2 \\
\hline Rpl32 & Ribosomal protein L32 & $\overline{\text { CB49448I }}$ & 3.7E-03 & protein biosynthesis - GO:00064I2 & -3.2 \\
\hline RPL36 & Ribosomal protein L36 & CA046196 & 3.3E-03 & protein biosynthesis - GO:00064I2 & -5.7 \\
\hline RPL36A & Ribosomal protein L36a & $\overline{\text { CB4999948 }}$ & 8.5E-04 & protein biosynthesis - GO:00064I2 & -4.8 \\
\hline Rpl37 & Ribosomal protein L37 & CB500526 & I.7E-02 & protein biosynthesis - GO:00064I2 & -3.7 \\
\hline Rpl39 & Ribosomal protein L39 & CB508357 & $9.0 \mathrm{E}-04$ & protein biosynthesis - GO:00064I2 & -3.7 \\
\hline RPL5 & Ribosomal protein L5 & CK991320 & $1.8 \mathrm{E}-02$ & protein biosynthesis - GO:00064I2 & -2.0 \\
\hline RPL7 & Ribosomal protein L7 & $\overline{\text { CK991334 }}$ & $8.3 \mathrm{E}-04$ & protein biosynthesis - GO:00064I2 & -3.1 \\
\hline RPL9 & Ribosomal protein L9 & $\overline{\mathrm{CB} 492853}$ & $1.2 \mathrm{E}-02$ & protein biosynthesis - GO:00064I2 & -2.8 \\
\hline Rps 12 & Ribosomal protein $\mathrm{SI} 2$ & $\overline{\text { CA769642 }}$ & $2.5 \mathrm{E}-03$ & protein biosynthesis - GO:00064I2 & -3.4 \\
\hline RPSI6 & Ribosomal protein SI6 & $\overline{\text { CB492970 }}$ & $5.8 \mathrm{E}-04$ & protein biosynthesis - GO:00064I2 & -5.5 \\
\hline RPSI8 & Ribosomal protein SI8 & $\overline{\mathrm{CB} 498298}$ & $5.4 \mathrm{E}-03$ & protein biosynthesis - GO:00064I2 & -2.3 \\
\hline Rps2I & Ribosomal protein S2I & $\underline{\mathrm{CA} 047 \mid 51}$ & $6.5 \mathrm{E}-03$ & protein biosynthesis - GO:00064I2 & -3.5 \\
\hline Rps23 & Ribosomal protein S23 & $\overline{\mathrm{CA} 042659}$ & 8.5E-04 & protein biosynthesis - GO:00064I2 & -5.9 \\
\hline Rps24 & Ribosomal protein $\mathrm{S} 24$ & CA769405 & $2.3 \mathrm{E}-02$ & protein biosynthesis - GO:00064I2 & -2.1 \\
\hline RPS25 & Ribosomal protein $\mathrm{S} 25$ & $\overline{\mathrm{CA} 050917}$ & $2.9 \mathrm{E}-03$ & protein biosynthesis - GO:00064I2 & -3.2 \\
\hline Rps26 & Ribosomal protein S26 & $\overline{\mathrm{CA} 061718}$ & $2.6 \mathrm{E}-02$ & protein biosynthesis - GO:00064I2 & -3.2 \\
\hline Rps 27 & Ribosomal protein $\mathrm{S} 27$ & CK990906 & 6.IE-04 & protein biosynthesis - GO:00064I2 & -3.7 \\
\hline Rps3 & Ribosomal protein S3 & $\overline{\mathrm{CA} 058850}$ & $5.8 \mathrm{E}-03$ & protein biosynthesis - GO:00064I2 & -2.3 \\
\hline Rps7 & Ribosomal protein S7 & $\overline{\text { CB504457 }}$ & 3.4E-03 & protein biosynthesis - GO:00064I2 & -4.2 \\
\hline Rplp2 & Ribosomal protein, large P2 & CB506488 & $7.2 \mathrm{E}-05$ & translational elongation - GO:00064I4 & -4.5 \\
\hline RPLPO & Ribosomal protein, large, PO & CA045397 & $6.9 \mathrm{E}-03$ & protein biosynthesis - GO:00064I2 & -2.0 \\
\hline Rplpl & Ribosomal protein, large, PI & CB496672 & $6.0 \mathrm{E}-03$ & protein biosynthesis - GO:00064I2 & -3.7 \\
\hline LOC363753 & Similar to 40 S ribosomal protein SI7 & $\overline{\text { CK991333 }}$ & $3.0 \mathrm{E}-03$ & protein biosynthesis - GO:00064I2 & -4.0 \\
\hline LOC66773I & Similar to 40 S ribosomal protein S2 & $\overline{\mathrm{CB} 498057}$ & 4.IE-03 & protein biosynthesis - GO:00064I2 & -2.0 \\
\hline LOC501619 & Similar to 40 S ribosomal protein $\$ 29$ & $\overline{\text { CK991092 }}$ & $3.9 \mathrm{E}-03$ & protein biosynthesis - GO:00064I2 & -6.0 \\
\hline LOC676999 & Similar to 40 S ribosomal protein $\mathrm{S} 6$ & $\overline{C B 496987}$ & $1.8 \mathrm{E}-03$ & protein biosynthesis - GO:00064I2 & -2.7 \\
\hline LOC675647 & Similar to 40 S ribosomal protein S7 (S8) & $\overline{\mathrm{CB} 492855}$ & $2.5 \mathrm{E}-02$ & protein biosynthesis - GO:00064I2 & -2.4 \\
\hline LOC666546 & Similar to $60 \mathrm{~S}$ acidic ribosomal protein $\mathrm{PI}$ & CB498269 & 2.IE-03 & protein biosynthesis - GO:00064I2 & -3.8 \\
\hline LOC498I35 & Similar to 60 S ribosomal protein LI8 & $\overline{\mathrm{CA} 061879}$ & 3.7E-02 & protein biosynthesis - GO:00064I2 & -2.7 \\
\hline MGC72957 & Similar to 60 S ribosomal protein LI8a & CB496920 & $1.0 \mathrm{E}-02$ & protein biosynthesis - GO:00064I2 & -3.6 \\
\hline LOC436164 & Similar to 605 ribosomal protein $\mathrm{L7a}$ & $\overline{\text { CK990919 }}$ & $1.0 \mathrm{E}-02$ & protein biosynthesis - GO:00064I2 & -2.6 \\
\hline RGDI309784 & Similar to ribosomal protein L24-like & $\overline{\mathrm{CB} 509952}$ & $2.0 \mathrm{E}-03$ & protein biosynthesis - GO:00064I2 & -2.8 \\
\hline EEFIAI & Eukaryotic translation elongation factor I alpha I & $\overline{\text { CB491069 }}$ & $1.5 \mathrm{E}-03$ & translational elongation - GO:00064I4 & -5.4 \\
\hline EEFIB2 & Eukaryotic translation elongation factor 1 beta 2 & $\overline{\mathrm{CB} 500560}$ & $1.8 \mathrm{E}-02$ & translational elongation - GO:00064I4 & -2.5 \\
\hline EIF2CI & Eukaryotic translation initiation factor $2 \mathrm{C}, \mathrm{I}$ & $\overline{\mathrm{CA} 055479}$ & I.2E-02 & protein biosynthesis - GO:00064I2 & 2.3 \\
\hline Eif2s2 & Eukaryotic translation initiation factor 2 , subunit 2 (beta) & CB499647 & $3.4 \mathrm{E}-04$ & protein biosynthesis - GO:00064I2 & 3.5 \\
\hline BTD & Biotinidase & CB492660 & 2.7E-04 & biotin metabolism - GO:0006768 & -8.7 \\
\hline SEC6IB & Sec6I beta subunit & $\overline{\text { CK991330 }}$ & $1.0 \mathrm{E}-02$ & protein targeting - GO:0006605 & -2.7 \\
\hline PPIA & Peptidylprolyl isomerase A (cyclophilin A) & $\overline{\text { CK990970 }}$ & $3.6 \mathrm{E}-04$ & protein folding - GO:0006457 & -4.8 \\
\hline Hsbpl & Heat shock factor binding protein I & $\overline{\mathrm{CB} 508758}$ & I.5E-05 & protein folding - GO:0006457 & -4.7 \\
\hline LOC290549 & Heat shock protein & $\overline{\mathrm{CB} 494575}$ & $3.5 \mathrm{E}-02$ & protein folding - GO:0006457 & -2.4 \\
\hline UBA52 & $\begin{array}{l}\text { Ubiquitin A-52 residue ribosomal protein fusion product } \\
\text { I }\end{array}$ & CB496916 & 2.7E-03 & protein biosynthesis - GO:0006412 & -3.7 \\
\hline Cog7 & Component of oligomeric golgi complex 7 & CA050633 & $2.2 \mathrm{E}-02$ & protein transport-GO:0015031 & 1.8 \\
\hline
\end{tabular}


Table 2: Differentially expressed genes of the mitochondrial functions and glucose metabolism

\begin{tabular}{|c|c|c|c|c|c|}
\hline Symbol & Gene name & ACC.\# & p value & GO Term & $\begin{array}{c}\text { Fold } \\
\text { change }\end{array}$ \\
\hline UCRC & Ubiquinol-cytochrome c reductase complex & $\underline{\mathrm{CA} 038364}$ & $2.0 \mathrm{E}-02$ & $\begin{array}{l}\text { electron transport - } \\
\text { GO:0006118 }\end{array}$ & -4.4 \\
\hline CYBRDI & Cytochrome b reductase $\mathrm{I}$ & CK990761 & $2.0 \mathrm{E}-02$ & $\begin{array}{l}\text { electron transport - } \\
\text { GO:0006118 }\end{array}$ & -2.4 \\
\hline COX4II & Cytochrome c oxidase subunit IV isoform I & CK990997 & $5.2 \mathrm{E}-04$ & $\begin{array}{l}\text { electron transport - } \\
\text { GO:0006118 }\end{array}$ & -3.3 \\
\hline COX6BI & Cytochrome c oxidase subunit Vib polypeptide I (ubiquitous) & $\underline{\mathrm{CA} 047209}$ & $7.9 \mathrm{E}-03$ & $\begin{array}{l}\text { electron transport - } \\
\text { GO:0006118 }\end{array}$ & -3.8 \\
\hline COX7A2 & Cytochrome c oxidase subunit VIla polypeptide 2 (liver) & $\underline{\mathrm{CB} 511353}$ & 4.4E-02 & $\begin{array}{l}\text { electron transport - } \\
\text { GO:0006118 }\end{array}$ & -3.1 \\
\hline Cox6c & Cytochrome c oxidase, subunit Vlc & $\underline{\mathrm{CA} 044426}$ & $2.4 \mathrm{E}-03$ & $\begin{array}{l}\text { electron transport - } \\
\text { GO:0006118 }\end{array}$ & -4.3 \\
\hline \multirow[t]{5}{*}{ Coxi7 } & Cytochrome c oxidase, subunit XVII assembly protein homolog & $\underline{\mathrm{CB} 507314}$ & $3.4 \mathrm{E}-02$ & $\begin{array}{l}\text { electron transport - } \\
\text { GO:0006118 }\end{array}$ & -2.2 \\
\hline & Similar to NP_008I89.1 cytochrome c oxidase subunit II & $\underline{\text { CA768526 }}$ & $3.5 \mathrm{E}-03$ & $\begin{array}{l}\text { electron transport - } \\
\text { GO:0006118 }\end{array}$ & -2.2 \\
\hline & Similar to NP_536845.I cytochrome c oxidase subunit I & $\underline{\text { CB494005 }}$ & $2.0 \mathrm{E}-04$ & $\begin{array}{l}\text { electron transport - } \\
\text { GO:0006118 }\end{array}$ & -3.1 \\
\hline & Similar to NP_006917.I cytochrome c oxidase subunit I & $\underline{\mathrm{CN} 442555}$ & $8.8 \mathrm{E}-03$ & $\begin{array}{l}\text { electron transport - } \\
\text { GO:0006118 }\end{array}$ & -2.4 \\
\hline & Similar to NP_536846.I cytochrome c oxidase subunit II & CN442553 & 4.3E-04 & $\begin{array}{l}\text { electron transport - } \\
\text { GO:0006118 }\end{array}$ & -6.0 \\
\hline ATP5GI & ATP synthase, $\mathrm{H}+$ transporting, mitochondrial F0 complex, $\mathrm{Cl}$ & CK991109 & 1.3E-02 & ATP synthesis - GO:0015986 & -2.5 \\
\hline ATP5J2 & ATP synthase, $\mathrm{H}+$ transporting, mitochondrial F0 complex, F2 & $\overline{\mathrm{CB} 493612}$ & $8.3 \mathrm{E}-03$ & $\begin{array}{l}\text { ATP biosynthesis - } \\
\text { GO:0006754 }\end{array}$ & -5.0 \\
\hline Atp5I & ATP synthase, $\mathrm{H}+$ transporting, mitochondrial F0 complex, $g$ & CB497057 & $3.5 \mathrm{E}-03$ & ATP synthesis - GO:0015986 & -3.3 \\
\hline ATP5B & ATP synthase, $\mathrm{H}+$ transporting, mitochondrial FI complex, beta & CK990869 & I.7E-04 & ATP synthesis - GO:0015986 & -3.9 \\
\hline \multirow[t]{2}{*}{ ATP6VIH } & ATPase, $\mathrm{H}+$ transporting, lysosomal $50 / 57 \mathrm{kDa}, \mathrm{VI}$ subunit $\mathrm{H}$ & CA053755 & 9.7E-03 & ion transport - GO:00068II & -2.4 \\
\hline & Similar to mitochondrial ATP synthase epsilon chain & CB496505 & $8.2 \mathrm{E}-04$ & $\begin{array}{l}\text { ATP biosynthesis - } \\
\text { GO:0006754 }\end{array}$ & -5.7 \\
\hline SUCLGI & Succinyl-CoA synthetase alpha subunit & $\underline{\text { CB49870I }}$ & $1.4 \mathrm{E}-02$ & $\begin{array}{l}\text { succinate-CoA ligase (GDP- } \\
\text { forming)-GO:0004776 }\end{array}$ & 4.2 \\
\hline SIc25a5 & Mitochondrial carrier, adenine nucleotide translocator, member 5 & CA058445 & $2.5 \mathrm{E}-02$ & transport - GO:0006810 & -2.6 \\
\hline SLC25A6 & Mitochondrial carrier; adenine nucleotide translocator, member 6 & CK990577 & $2.2 \mathrm{E}-02$ & transport - GO:0006810 & -2.4 \\
\hline SLC25A25 & Mitochondrial carrier; phosphate carrier, member 25 & CA042906 & 3.IE-03 & transport - GO:0006810 & -3.9 \\
\hline TOMM7 & Translocase of outer mitochondrial membrane 7 & CB497943 & $1.0 \mathrm{E}-03$ & $\begin{array}{l}\text { protein transport - } \\
\text { GO:001503I }\end{array}$ & -3.7 \\
\hline TOMM40 & Translocase of outer mitochondrial membrane 40 & CB498734 & $2.4 \mathrm{E}-04$ & $\begin{array}{l}\text { lipid transporter activity - } \\
\text { GO:0005319 }\end{array}$ & 5.4 \\
\hline GAPDH & Glyceraldehyde-3-phosphate dehydrogenase & CA050886 & $4.8 \mathrm{E}-03$ & GO:0003824 : catalytic activity & -2.9 \\
\hline RPIA & Ribose 5-phosphate isomerase A (ribose 5-phosphate epimerase) & CB503502 & $1.2 \mathrm{E}-02$ & $\begin{array}{l}\text { pentose-phosphate shunt - } \\
\text { GO:0009052 }\end{array}$ & 1.8 \\
\hline $\begin{array}{l}\text { ST6GALNA } \\
\text { C6 }\end{array}$ & $\begin{array}{l}\text { ST6 (alpha- } \mathrm{N} \text {-acetyl-neuraminyl-2,3-beta-galactosyl-I,3)-N- } \\
\text { acetylgalactosaminide alpha-2,6-sialyltransferase } 6\end{array}$ & CA050762 & $2.4 \mathrm{E}-02$ & $\begin{array}{l}\text { carbohydrate metabolism - } \\
\text { GO:0005975 }\end{array}$ & -2.0 \\
\hline Fahd I & Fumarylacetoacetate hydrolase domain containing I & CB492598 & I.5E-02 & metabolism - GO:0008I52 & -2.2 \\
\hline Tat & Tyrosine aminotransferase & CA056381 & $2.6 \mathrm{E}-02$ & $\begin{array}{l}\text { amino acid and derivative } \\
\text { metabolism - GO:0006519 }\end{array}$ & -2.5 \\
\hline FUK & Fucokinase & $\underline{\mathrm{CA} 040903}$ & $5.5 \mathrm{E}-04$ & $\begin{array}{l}\text { fucokinase activity - } \\
\text { GO:005020I }\end{array}$ & 4.7 \\
\hline Ces2 & Carboxylesterase 2 & CA039230 & 4.3E-02 & catabolism - GO:0009056 & 1.7 \\
\hline Ces6 & Carboxylesterase 6 & $\overline{\mathrm{CB} 496876}$ & $2.8 \mathrm{E}-02$ & $\begin{array}{l}\text { carboxylesterase activity - } \\
\text { GO:000409I }\end{array}$ & 1.7 \\
\hline SAT & Spermidine/spermine NI-acetyltransferase & CB488575 & $3.4 \mathrm{E}-03$ & $\begin{array}{l}\text { diamine } \mathrm{N} \text {-acetyltransferase } \\
\text { activity - GO:0004 I } 45\end{array}$ & 3.8 \\
\hline
\end{tabular}

such as protein and lipids are catabolized for energy [24]. The stabilized expression of most glycolytic pathway enzymes may be to preserve the enzymatic machinery of the gluconeogenesis. While the activities of most pathways are reduced during starvation, some pathways, such as gluconeogenesis, may remain unaltered or become enhanced $[25,26]$ in vital tissues during the initial stages of fish starvation. Glucose is needed for the continued function of essential organs like brain. Another explanation for the maintenance of glycolytic enzymes' expres- sion is short duration of feed deprivation (3 weeks) used in this experiment.

\section{The antioxidant systems}

In starved fish, reduced expression of a number of transcripts related to maintenance of intracellular redox status was observed. These transcripts include 4 glutathione Stransferase (GST) transcripts and the glutathione peroxidase (GPX) gene (Table 3). These genes encode for antioxidants required to defend against reactive oxygen species (ROS) generated during the aerobic metabolic 
activities. GPX breaks down hydrogen peroxide [27] and GST conjugates reduced glutathione to xenobiotics or cellular components damaged by ROS [28]. Another downregulated transcript is Hydroxyacid oxidase (Hao1) whose expression has been shown to be liver-specific and targeted to peroxisomes. Hao1 belongs to a family of enzymes that convert a broad range of $\alpha$-hydroxy acids to $\alpha$-keto acids and concomitantly reduce molecular oxygen to $\mathrm{H}_{2} \mathrm{O}_{2}$ [29]. Oxidative activities of mitochondria are a primary endogenous source of the reactive oxygen species (ROS). Consequently, we predict that, as the rate of ROS generation is decreased as a result of reduced aerobic metabolism in starved fish, the rate of the cellular antioxidants generation is decreased as well.

Several members of the antioxidant systems that keep intracellular redox homeostasis including thioredoxin, glutaredoxin-like transcripts and disulfide reductases exhibited decreased expression in starved fish (Table 3 ). Jimenez and coworkers [30] reported that glucose deprivation reduced levels of thioredoxin-like protein. Conversely, its over-expression protects against glucose deprivation-induced cytotoxicity. Consequently, our results support the assertion that thioredoxin might be involved in cellular response to starvation stress.

\section{Lipid and prostaglandin metabolism}

Fish use lipids as the major energy source in contrast to mammals that depend primarily on carbohydrates [31]. Microarray analysis revealed a decreased mRNA accumulation of the apolipoproteins including Apob, Apoa1, Apoc1, Apoc2, Apoe, and Apoh in starved fish (Table 4). Apolipoproteins are plasma lipoprotein complexes that are synthesized mainly in the liver, bind to lipids, and transport them to different tissues through circulation [32].

Starved fish showed reduced mRNA accumulation of the fatty acid binding proteins, FABP1 and FABP3 and the retinol binding proteins, RBP1 and RBP2 (Table 4). FABPs and RBPs are collectively referred to as the intracellular lipid binding proteins. RBPs bind retinoids, which are essential for growth, vision, reproduction, hematopoiesis and immune function. FABPs play an important role in the intracellular uptake and transport of long-chain fatty acids through the aqueous cytoplasm to the site of their oxidation in the mitochondria or peroxisomes [33]. FABPs concentration increases with treatments that increase fatty acid metabolism, and it is positively correlated with the ability of tissues to metabolize fat [34]. Down-regulated expression of FABPs suggests reduced hepatic fatty acid metabolism that may contribute to the aforementioned overall decrease in mitochondrial ATP production in starved fish.
The microarray data did not reveal any elevated expression of the liver fatty acid oxidation mechanisms in starved fish suggesting that rainbow trout may mobilize fat from extra-hepatic resources to fuel metabolism during feed deprivation. Jeziersk and colleagues [35] reported that upon starvation, visceral lipid contributed the most to energy metabolism compared to muscle and liver fat depots. The absolute amount of fat derived from the liver was much smaller than that of muscle and viscera. Rasmussen and coworkers [36] reported that a 50\% increase in feed lipid content enhanced fillet lipid levels by $20 \%$ and caused a $15-20 \%$ increase in the visceral fraction. Our previous results, using microarray and proximate analyses, did not reveal any significant modification of the lipolysis pathways in atrophying rainbow trout muscle $[4,37]$. Collectively, our results indicate that visceral fat is the first to be mobilized and perhaps the most important fat depot for energy in rainbow trout [35]. Liver and muscle lipids may be less mobile than visceral lipid. Detailed studies are needed to explore different mechanisms that regulate lipid mobilization from visceral, liver and muscle stores.

A significant decrease in mRNA accumulation of the fatty acid desaturase 2 gene (FADS2) was observed in starved fish (Fig. 1, Table 4). FADS2 is a terminal component of the liver lipogenic microsomal stearyl-CoA desaturase system that uses $\mathrm{O}_{(2)}$ and electrons from reduced cytochrome b5 to catalyze the insertion of a double bond into a spectrum of fatty acyl-CoA substrates, including palmitoylCoA and stearoyl-CoA. The closely related desaturase, FADS1, is a key regulatory enzyme of unsaturated fatty acid biosynthesis [38]. Jezierska and coworkers [35] reported a decline in the hepatic percentage of the monoenoic fatty acid upon starvation of rainbow trout; whereas, the saturates remained relatively constant and polyunsaturates increased. Smith and colleagues [39] reported that monounsaturated fatty acids, $16: 1 \mathrm{n}-7,18: 1 \mathrm{n}-9$ and $18: 1 \mathrm{n}-7$, of the spiny lobster, Jasus edwardsii decreased with starvation. These results indicate diet-dependent adaptive shifts in fish relative fatty acid composition. Unsaturated fatty acids are needed for their unique physical properties in biological membranes [40]. Nevertheless, unsaturated fatty acids are synthesized at considerable energetic cost; approximately 10 ATP are used for each desaturation and 2-carbon elongation. Consequently, it may be advantageous to delay synthesizing these costly molecules until feeding is resumed.

Starved fish exhibited reduced mRNA accumulation of prostaglandin D2 synthase 2 (Ptgds2). Ptgds2 is the precursor of 15-deoxy-delta12-14-prostaglandin J2 (15dPGJ2) that plays a critical role in fat cell differentiation, inducing the expression of adipocyte-specific genes and promoting the formation of mature, lipid-laden adi- 
Table 3: Differentially expressed genes of the antioxidant system

\begin{tabular}{|c|c|c|c|c|c|}
\hline Symbol & Gene name & ACC.\# & p value & GO Term & $\begin{array}{l}\text { Fold } \\
\text { change }\end{array}$ \\
\hline GSTO2 & Glutathione S-transferase omega 2 & CA064086 & 2.9E-03 & metabolism - GO:0008I52 & -3.8 \\
\hline GSTPI & Glutathione S-transferase pi & $\underline{\mathrm{CA} 050452}$ & I.0E-03 & $\begin{array}{l}\text { glutathione transferase activity - } \\
\text { GO:0004364 }\end{array}$ & -7.1 \\
\hline GSTZI & $\begin{array}{l}\text { Glutathione transferase zeta I } \\
\text { (maleylacetoacetate isomerase) }\end{array}$ & CB492382 & $6.9 \mathrm{E}-03$ & $\begin{array}{l}\text { L-phenylalanine catabolism - } \\
\text { GO:0006559 }\end{array}$ & -4.5 \\
\hline MGST3 & Microsomal glutathione S-transferase 3 & CA061668 & 8.IE-03 & lipid metabolism - GO:0006629 & -5.3 \\
\hline GPX4 & $\begin{array}{l}\text { Glutathione peroxidase } 4 \text { (phospholipid } \\
\text { hydroperoxidase) }\end{array}$ & $\underline{\text { CB510303 }}$ & I.2E-02 & $\begin{array}{l}\text { phospholipid metabolism - } \\
\text { GO:0006644 }\end{array}$ & -3.1 \\
\hline HAOI & Hydroxyacid oxidase (glycolate oxidase) I & CB502864 & 4.IE-02 & $\begin{array}{l}\text { fatty acid alpha-oxidation - } \\
\text { GO:000I56I }\end{array}$ & -2.4 \\
\hline TXN & Thioredoxin & CA057296 & $2.2 \mathrm{E}-05$ & electron transport - GO:00061I8 & -6.8 \\
\hline LOC389207 & Similar to glutaredoxin cysteine-rich I protein & CB496770 & 7.3E-03 & electron transport - GO:0006118 & -3.0 \\
\hline
\end{tabular}

pocytes [41]. In addition, adipose differentiation-related protein (ADFP) expression was reduced in starved fish. ADFP is associated with early stages of adipocyte differentiation and may play a critical role in regulating the formation, turnover and metabolic consequences of fat formation in mammalian extra adipose tissues [42]. Collectively, gene expression data, relative to lipid metabolism, suggest that the need to reduce metabolic energy costs has slowed down mechanisms of lipid and fatty acid synthesis, lipid binding and transportation and adipocyte differentiation. More detailed investigations on fish may add new insights into the molecular evolution of the mechanisms regulating lipogenesis and lipolysis processes and should become the objective of further studies.

\section{Blood function}

Starvation reduced expression of many iron homeostasis and blood function-related genes including oxygen carrier hemoglobin (HB), alpha and beta; plasma iron transport protein, transferrin; and the iron storing protein, ferritin (Table 5). Heme binding protein 1 was up-regulated in starved fish. Transcripts of blood coagulation proteins, fibrinogen, plasminogen, thrombin receptor, and antithrombin (SERPINC1) were down-regulated in starved fish. Haptoglobin, which binds free HB leaking from red blood cells under pathological conditions to protect against its harmful oxidative effects [43], was also down regulated. In addition, the important cardiovascular and body fluid homeostasis gene, natriuretic peptide precursor A [44] was down-regulated in starved fish. Collectively, these data suggest that iron homeostasis functions are compromised in starved fish. Head kidney is the main hematopoietic tissue in fish [45], however, liver is a highly vascularized tissue. Consequently, the contradictory expression of the liver iron homeostasis transcripts may be due to the red blood cells entering the liver.

\section{Immune response}

Several immune-relevant genes were down-regulated in response to starvation (Table 6). The list includes 4 components of the complement system, C3, C5, CFB and CFP; 2 transcripts of C-type lectins, and the aforementioned transferrin, prostaglandin D2 synthase, glutathione peroxidases and hepatoglobin genes. These transcripts were identified by CDNA subtractive libraries as liver-made defense molecules and members of the fish innate immune system. These genes are inducible when fish are challenged with bacterial infection [46,47]. Furthermore, hepcidin, a potent antimicrobial peptide and important member of the fish innate immune system [48], was down-regulated, and transferrin, which is a positive acute phase protein in rainbow trout [49] was also down-regu-

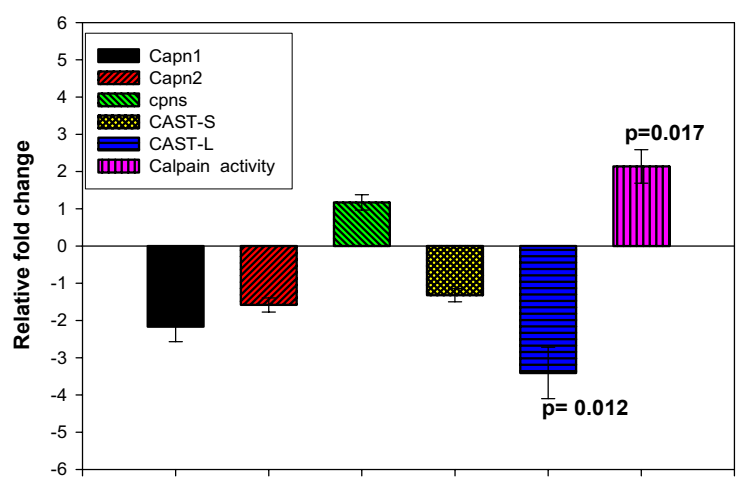

\section{Figure 3}

Effect of starvation on rainbow trout liver mRNA accumulation of the calpain catalytic subunits (CapnI and Capn2), the regulatory subunit (cpns), the calpain inhibitors (CAST-L and CAST-S) and the corresponding calpain enzyme activity. Only significant $p$ values are shown (Means \pm S.E., $n=6$ ). 
Table 4: Differentially expressed genes of the lipid metabolism

\begin{tabular}{|c|c|c|c|c|c|}
\hline Symbol & Gene name & ACC.\# & p value & GO Term & $\begin{array}{l}\text { Fold } \\
\text { change }\end{array}$ \\
\hline APOB & Apolipoprotein $B$ (including $\mathrm{Ag}(\mathrm{x})$ antigen) & CB5111166 & I.7E-02 & lipid metabolism - GO:0006629 & -4.1 \\
\hline Apoal & Apolipoprotein A-I & $\underline{\mathrm{CB} 510796}$ & I.5E-03 & lipid transport - GO:0006869 & -3.0 \\
\hline Apocl & Apolipoprotein C-I & CA037557 & I.7E-03 & transport - GO:0006810 & -4.6 \\
\hline APOC2 & Apolipoprotein C-II & CB496914 & I.8E-02 & lipid transport - GO:0006869 & -2.4 \\
\hline Apoe & Apolipoprotein E & $\overline{\mathrm{CB} 506103}$ & $2.3 \mathrm{E}-02$ & lipid transport - GO:0006869 & -2.2 \\
\hline \multirow[t]{2}{*}{$\mathrm{APOH}$} & Apolipoprotein H (beta-2-glycoprotein I) & $\overline{\mathrm{CB} 492833}$ & I.3E-02 & defense response - GO:0006952 & -2.4 \\
\hline & $\begin{array}{l}\text { Similar to NP_000473.I apolipoprotein A-IV } \\
\text { precursor }\end{array}$ & $\underline{\text { CB49697I }}$ & I.7E-02 & lipid transport - GO:0006869 & -3.0 \\
\hline FABPI & Fatty acid binding protein I, liver & CB509924 & $1.6 \mathrm{E}-03$ & fatty acid metabolism - GO:000663I & -5.0 \\
\hline Fabp3 & Fatty acid binding protein 3 , muscle and heart & $\underline{\mathrm{CB} 507515}$ & 3.IE-02 & $\begin{array}{l}\text { phosphatidylcholine biosynthesis - } \\
\text { GO:0006656 }\end{array}$ & -2.1 \\
\hline RBPI & Retinol binding protein I, cellular & $\underline{\mathrm{CB} 492550}$ & 4.IE-04 & vitamin A metabolism - GO:0006776 & -4.5 \\
\hline RBP2 & Retinol binding protein 2, cellular & CB496593 & 8.5E-04 & vitamin A metabolism - GO:0006776 & -4.5 \\
\hline FADS2 & Fatty acid desaturase 2 & $\overline{\mathrm{CB} 494661}$ & 3.IE-04 & fatty acid desaturation - GO:0006636 & -9.5 \\
\hline Ptgds2 & Prostaglandin D2 synthase 2 & $\underline{\mathrm{CA} 038730}$ & I.IE-02 & $\begin{array}{l}\text { prostaglandin biosynthesis - } \\
\text { GO:0001516 }\end{array}$ & -2.7 \\
\hline ADFP & Adipose differentiation-related protein & CB514104 & $9.5 \mathrm{E}-03$ & lipid metabolism - GO:0006629 & -3.5 \\
\hline
\end{tabular}

lated in starved fish. Transferrin, ferritin and hepcidin modulate iron homeostasis [50]; hence, they may control bacterial proliferation by limiting iron availability [51]. Down-regulation of the immune-relevant genes suggests mechanisms by which starved fish may demonstrate weakened pathogen resistance.

On the other hand, few immune-relevant genes showed up-regulated expression in response to starvation (Table 6). Two transcripts belonging to the T cell receptor system that is involved in adaptive (lymphoid) immune responses [51] were up-regulated. In addition, starved fish exhibited increased expression of the tartrate-resistant acid phosphatase (ACP5) gene. Macrophages from mice over expressing ACP5 showed increased capacity for killing bacteria [52]. Lymphoid cells entering liver from circulation may be responsible for this change.

The immune response includes synthesis of potent antioxidants to protect cells against oxidative damage [53]. Starved fish exhibited reduced expression of several genes involved in managing oxidative stress, including glutathione $S$-transferases and glutathione peroxidases. These genes were consistently up-regulated in Piscirickettsia salmonis-infected macrophages of Atlantic salmon [51]. On the other hand, cytochrome P450 CYP1A1 and CYP3A43, which are components of the necessary detoxification pathway [54], were up-regulated in starved fish.

\section{Miscellaneous functions}

Starved fish showed down-regulation of many transcripts classified into various functions including transcriptional housekeeping genes, transcription factors and regulators and genes belonging to several signal transduction path- ways. A complete list of the differentially expressed genes is available at NCBI Gene Expression Omnibus (GEO) database with the accession number: GSE6944 [55].

\section{Proteolysis and amino acid metabolism}

Fish swiftly use proteins as oxidative substrates [8]. Protein turnover is a crucial determinant in converting feed into growth [2]. During starvation, fractional protein-degradation rate increases significantly [9]. Protein degradation is a tightly controlled and regulated process that depends on at least three major proteolytic enzyme pathways $[4,5]$. Consequently, gene expression of these enzyme systems is expected to increase in starved fish. However, starved fish showed reduced expression of a number of transcripts related to amino acid and proteolysis functions (Table 7). Two proteasome and 3 ubiquitin transcripts were also down-regulated in starved fish.

\section{Evaluation of protease gene expression using real-time PCR and enzyme activity assays}

Since the microarray approach did not show significant changes of gene expression in protein catabolic pathways, we decided to use real-time PCR and the enzyme activity assays to measure the expression of genes and enzyme activities in the major proteolytic systems.

As shown in Fig. 3, starvation did not affect the mRNA levels for Capn1, Capn2, cpns and CAST-S ( $p>0.05$ ). However, a significant decrease in CAST-L expression ( $\mathrm{p}=$ 0.012 ), with a corresponding increase in the calpain catalytic activity, was observed in starved fish (Fig. 3, p = $0.017)$. Our results are consistent with a previous report showing that during starvation, activity of the calpain sys- 
Table 5: Differentially expressed genes of the blood functions

\begin{tabular}{|c|c|c|c|c|c|}
\hline Symbol & Gene name & ACC.\# & p value & GO Term & $\begin{array}{l}\text { Fold } \\
\text { change }\end{array}$ \\
\hline HBAI & Hemoglobin, alpha I & CB500796 & I.2E-04 & oxygen transport - GO:001567I & -3.7 \\
\hline Hba-al & Hemoglobin alpha, adult chain I & $\underline{\text { CB497424 }}$ & 2.7E-04 & oxygen transport - GO:001567I & -5.4 \\
\hline $\mathrm{Hbb}$ & Hemoglobin beta & CB498575 & $6.8 \mathrm{E}-04$ & oxygen transport - GO:001567I & -5.7 \\
\hline TF & Transferrin & $\underline{\text { CB496720 }}$ & 2.IE-02 & iron ion transport - GO:0006826 & -4.6 \\
\hline Hebpl & Heme binding protein I & $\underline{\mathrm{CA} 043780}$ & $8.9 \mathrm{E}-04$ & heme metabolism - GO:0042168 & 4.3 \\
\hline FTHI & Ferritin, heavy polypeptide I & CB507396 & I.3E-03 & ferritin complex - GO:0008043 & -4.9 \\
\hline$F 2 R$ & Coagulation factor II (thrombin) receptor & CB49347I & $2.9 \mathrm{E}-02$ & blood coagulation - GO:0007596 & -2.1 \\
\hline SERPINCI & $\begin{array}{l}\text { Serpin peptidase inhibitor, clade C (antithrombin), } \\
\text { member I }\end{array}$ & CA038790 & 2.7E-03 & blood coagulation - GO:0007596 & -3.1 \\
\hline Fgg & Fibrinogen, gamma polypeptide & CA039531 & 5.IE-04 & blood coagulation - GO:0007596 & -3.1 \\
\hline $\mathrm{Plg}$ & Plasminogen & CA037954 & 7.4E-03 & blood coagulation - GO:0007596 & -3.9 \\
\hline HP & Haptoglobin & CB510638 & 7.IE-04 & iron homeostasis - GO:0006879 & -2.3 \\
\hline NPPA & Natriuretic peptide precursor A & BU965660 & 7.7E-03 & $\begin{array}{l}\text { blood pressure regulation - } \\
\text { GO:0008217 }\end{array}$ & -6.1 \\
\hline Hemtl & Hematopoietic cell transcript I & CB512520 & I.8E-03 & protein folding - GO:0006457 & -2.8 \\
\hline NargI & NMDA receptor-regulated gene I & CA063821 & $3.2 \mathrm{E}-03$ & angiogenesis - GO:000I 525 & 2.3 \\
\hline
\end{tabular}

tem in bovine skeletal muscle is controlled through decrease in expression of CAST [56].

CAST is a specific and the only known endogenous inhibitor of the calpain system. Mammalian experiments showed that $\beta$-adrenergic agonist administration decreases protein degradation through increased expression of the CAST gene [57]. CAST is associated with the muscle fractional degradation rate [58] and reduced muscle wastage in experimental animals [59]. Studies on the importance of CAST gene in fish are still limited. Previously, we reported that calpains play an important role in muscle proteolysis fueling metabolism of rainbow trout during starvation [6]. In addition, CAST-L and CAST-S mRNA were positively associated with muscle growth and firmness in rainbow trout [7]. The present results indicate that the calpain pathway may be involved in mobilizing hepatic proteins during starvation. The current study supports the importance of CAST gene in controlling fish protein turnover, and suggests that CAST-L may be a good candidate as a biomarker for fish protein accretion. Data collected recently in our lab indicated that the CAST-L and CAST-S genes are polymorphic in rainbow trout strains/ crosses (unpublished data). More detailed studies to determine the physiological roles of CAST and the association of its polymorphisms with economically important traits in farmed fish are needed and are being currently conducted in our lab.

Real time PCR analyses revealed no significant difference in expression of any of the studied proteasome genes including subunit alpha 5, subunit beta 3, the regulatory subunit 6, subunit $\mathrm{N} 3$ and poly-ubiquitin (Fig. $4 \mathrm{C}, \mathrm{p}=$ 0.01 ). Unexpectedly, the corresponding $20 \mathrm{~S}$ proteasome activity was slightly but significantly higher in starved fish
(Fig. $4 \mathrm{~F}, \mathrm{p}=0.039$ ), suggesting a post-transcriptional regulatory effect of starvation on proteasome enzymatic activity. The ubiquitin-proteasome pathway is primarily responsible for proteolysis of normal mammalian muscle [60]. However, studies on fish indicate that the ubiquitinproteasome proteolytic pathway is down-regulated in liver and muscle of starved rainbow trout without affecting mRNA of the proteasome N3 [61]. Our previous studies showed that the ubiquitin-proteasome system is not up-regulated during spawning-induced muscle proteolysis in rainbow trout $[4,37]$. Dobly and coworkers reported that proteasome activity in liver, but not in muscle, was negatively correlated with growth rates in rainbow trout [62]. These contradicting results suggest that our current observation of increased proteasome activity may represent a temporal change. Additional studies are needed to characterize the role of the proteasome system in fish protein accretion.

The mRNA abundance for cathepsins $\mathrm{D}$ and $\mathrm{L}$ and their corresponding enzyme activities were not affected by starvation as shown in Fig. 5 ( $\mathrm{p}>0.05)$. Our previous reports indicated that lysosomal cathepsins, particularly cathep$\sin -\mathrm{L}$, are the key proteases in spawning-induced proteolysis in rainbow trout $[4,37]$. In addition, we reported that $\beta$-adrenergic agonist administration reduced rainbow trout muscle cathepsin D activity [5]. The cathepsin pathway appears to play a major role in mobilizing muscle protein in salmonids, particularly when they cease feeding during their prolonged spawning migration [63]. Guderley found that, in Atlantic cod, hepatic contents of lysosomal proteases decreased with prolonged starvation, whereas in white muscle, starvation doubled specific activity of cathepsin D [27]. These results indicate that 
cathepsins may be less important in mobilizing hepatic proteins than in muscular proteins.

\section{Conclusion}

The major responses of rainbow trout liver to starvation are: 1) a generalized decline in gene expression associated with a decrease in tissue metabolism, 2) an overall reduction in protein synthetic capacity, 3) impairment of mitochondrial (aerobic) ATP-biosynthetic functions while maintaining liver glycolytic/gluconeogenic competence, 4) down-regulated expression in mechanisms associated with hepatic lipid and fatty acid transport while maintaining fatty acid oxidation mechanisms, 5) significant increases in calpain and proteasome catabolic pathways, 6) fish may maintain tight-control on the mechanisms of protein metabolism more than lipid or carbohydrate under short term starvation condition and 7) extrahepatic tissues, especially visceral fat, may play a major role in lipid metabolism upon starvation.

Maintenance of glycolytic expression may represent a short term effect ( 3 weeks) and suggest that normal turnover of energy reserves may be sufficient to maintain energy requirements during the initial stages of food deprivation. Nevertheless, the overall decrease of expression is indicative of a long-term metabolic response that aims to conserve energy reserves and enhance the ability to survive until feed is available. The use of microarray approach and enzyme activity measurements has allowed us to follow more closely the metabolic changes occurring during starvation. More detailed work is necessary to identify specific steps that control individual metabolic pathways and thereby determine energy use during starvation. The CAST-L gene is an appealing candidate as a potential biomarker for fish protein accretion. More detailed studies are needed to explore the physiological roles of the CAST-L gene in fish growth.

\section{Methods}

\section{Fish and tissue sampling}

The rainbow trout (Oncorhynchus mykiss) used in this study were from the National Center for Cool and Cold Water Aquaculture (NCCCWA) strain [64]. Prior to the study, the fish were reared under standard laboratory practices, and were fed to apparent satiation daily. A typical commercial trout feed was used (Zeigler Gold, Zeigler Bros. Inc, Garners, PA) with $42 \%$ crude protein and $16 \%$ crude fat. For both treatments six fish were each reared in a separate 10-liter tank for a total of 12 tanks. The fish were acclimated to the individual rearing units for 2 weeks prior to the study and all fish were feeding well at the initiation of the treatments. Water temperature was maintained at $14^{\circ} \mathrm{C}$, and dissolved oxygen concentration was maintained close to saturation. Initial weight of the fish in the two treatments was not different $(P>0.37)$ at $193.0 \pm$
15.7 g. After 3 weeks the feed deprived fish weighed significantly less than the fed fish, $279.7 \pm 19.8$ g versus 172.0 $\pm 10.6 \mathrm{~g}$. For the final weighing, fish were anesthetized one at a time with $0.1 \mathrm{mg} / \mathrm{L}$ MS-222. After weighing, a piece of liver was rapidly removed and placed in $1.5-\mathrm{ml}$ test tubes, flash frozen in liquid nitrogen and then kept at $-80^{\circ} \mathrm{C}$ until sample preparation. All animal handling and sampling procedures were reviewed and approved by the NCCCWA Institutional Animal Care and Use Committee.

\section{RNA preparation}

Total RNA was isolated from each fish ( 6 fish/group) using Trizol reagent (Invitrogen, Carlsbad, CA) according to the manufacturer's instruction. Concentrations of isolated RNA were determined by measuring absorbance at $260 \mathrm{~nm}$. The integrity of RNA was determined by agarose gel electrophoresis. Poly (A) mRNA was purified using Oligotex mRNA Mini Kit (Qiagen, Valencia, CA) according to the manufacturer's instruction.

\section{Microarrays, cDNA labeling and hybridization}

A salmonid microarray containing cDNAs representing 16,006 genes selected from Atlantic salmon and rainbow trout expressed sequence tag databases $[37,65]$ was used in the study. The microarray has been validated as a useful tool for rainbow trout studies [65]. A compete list of the genes on the array is available at the database of Consortium for Genomic Research on All Salmon Project [66]. Microarray slides were purchased from Dr. Ben Koop's laboratory at the University of Victoria. Arrays were performed on 4 independent fed and 4 independent fasted

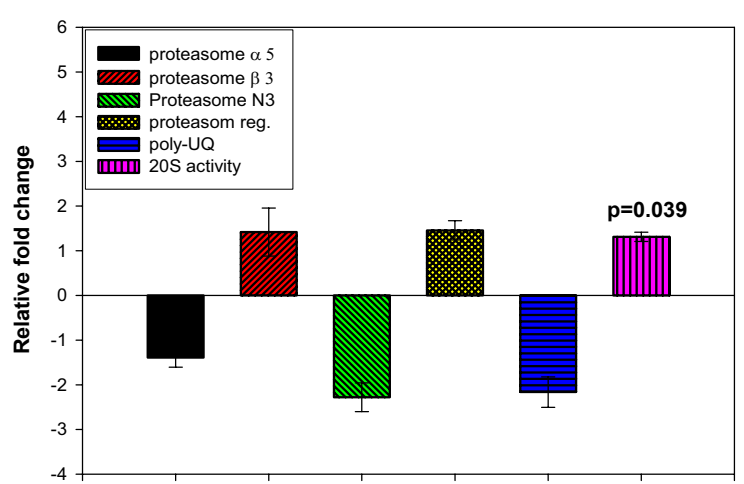

\section{Figure 4}

Effect of starvation on rainbow trout liver mRNA accumulation of the proteasome pathway genes (catalytic subunits alpha 5 , beta 3 and N3, the regulatory subunit and polyubiquitin) and the corresponding enzyme activity of the $20 \mathrm{~S}$ proteasome. Only significant $\mathrm{p}$ values are shown (Means \pm S.E., $n$ $=6$ ). 


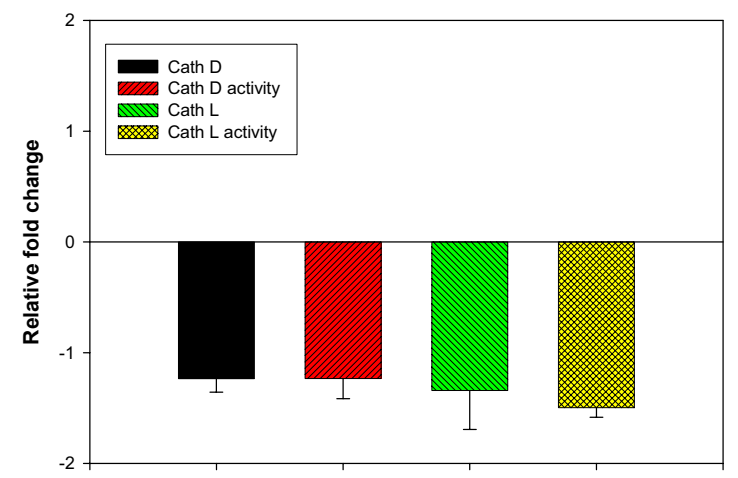

\section{Figure 5}

Effect of starvation on rainbow trout liver mRNA accumulation of cathepsins $D$ and $L$ and their corresponding enzyme activities. No significant difference was found (Means \pm S.E., $n$ $=6$ ).

liver samples (4 biological replicates). Fluorophors (Cy3 and Cy5) were randomly assigned to RNA from each of the starved and fed fish to limit the dye effect. cDNA labeling and microarray hybridization procedures were essentially as we previously described $[37,67]$. Briefly, $0.4 \mu \mathrm{g}$ of mRNA from each rainbow trout tissue was used as a template in reverse transcription reactions incorporating amino-allyl dUTP into the cDNA using oligo-d (T) primer and Superscript II reverse transcriptase (Invitrogen, Carlsbad, CA). The synthesized cDNAs from each starved and fed fish were differentially labeled using N-hydroxysuccinate-derived Cy3 or Cy5 dyes (GE Healthcare, Piscataway, NJ). Labeled cDNAs were purified using a PCR purification kit (Roche, Indianapolis, IN) to remove unincorporated dyes. The Cy3 and Cy5 labeled cDNAs were then combined and concentrated down to $20 \mu \mathrm{l}$ using a Vacufuge vacuum concentrator (Eppendorf, Westbury, NY) followed by addition of $130 \mu \mathrm{l}$ of Slidehyb 3 solution (Ambion, Inc. Austin, TX). Microarray hybridizations were performed on a Tecan HS400 automated microarray hybridization station (Tecan US, Durham, NC). The slides were placed on the machine at $60^{\circ} \mathrm{C}$ for 2 minutes followed by pre-hybridization at $55^{\circ} \mathrm{C}$ for 30 minutes with pre-hybridization solution $(5 \times$ SSC, $1 \%$ SDS, $1 \%$ BSA $)$ under medium agitation. After a brief washing at $60^{\circ} \mathrm{C}$ for 1 minute, differentially labeled cDNAs in hybridization buffer $(\sim 145 \mu \mathrm{l})$ were injected into the hybridization chamber. The hybridizations were carried out for 3 hours at $60^{\circ} \mathrm{C}$ followed by another 13 hours at $55^{\circ} \mathrm{C}$. Arrays were washed twice in $2 \times$ SSC, $01 \%$ SDS, followed by twice in $0.1 \times$ SSC, $0.1 \%$ SDS at room temperature. Following 2 more washes in $0.1 \times$ SSC, the slides were rinsed in water and dried by centrifugation.

\section{Microarray scanning and data analysis}

ScanArray Lite ${ }^{\circledast}$ microarray scanner was used to scan arrays and ScanArray Express ${ }^{\circledast}$ software (PerkinElmer, Wellesley, $\mathrm{MA}$ ) was used to process array images, align spots, integrate robot-spotting files with the microarray images and quantify spots as we previously described [37]. Preprocessing and normalization of data were accomplished using the R-project statistical environment [68] and Bioconductor [69] through the GenePix AutoProcessor (GPAP) [70]. Data were pre-processed by: 1) Removing data points where signal intensities in both channels were less than a baseline threshold value of 200,2) Calculating and subtracting local background fluorescence values from all feature intensities, 3) Log2-transforming the background subtracted Cy3/Cy5 ratios, 4) Calculating means of intensities within and across biological replicates, and 5) Defining spots that are larger or smaller than 2 standard deviations from the mean as outliers and eliminating them from calculation of the final means of $\log 2$ ratios within and across the biological replicate arrays. All hybridizations were also subjected to manual review to ensure flagging and exclusion of all unacceptable spots. Following pre-processing, the expression results were normalized using global LOWESS normalization to adjust and balance individual signal intensities to reduce any systematic or technical variations. Diagnostic box plots of LOWESS normalized Log2 ratios were used to ensure that biological replicate arrays were similar in range. For each spot, t-statistic, P-value (probability), and fold change were calculated. Spots with one and half-fold change or more were considered differentially expressed using $\mathrm{p}$ value $<0.05$. Four experiments were conducted. Microarray data were deposited (according to Microarray Gene Expression Data Society Standards) in the NCBI Gene Expression Omnibus with the series accession number: GSE6944 [55].

\section{Quantitative real-time PCR analysis}

Quantitative real time PCR was used to confirm the expression of 5 differentially expressed genes identified by microarray experiments. In addition, real time PCR was also used to measure the mRNA levels of genes pertinent to 1 ) the calpain/calpastatin proteinase pathway $[6,7]$ including the catalytic subunits of $\mu$-calpain (Capn 1 ) and m-calpain (Capn2), the calpain regulatory subunit (cpns), the calpastatin long isoform (CAST-L) and the calpastatin short isoform (CAST-S), 2) the proteasome multicatalytic pathway including proteasome subunits alpha 5, beta 3 , N3, regulatory subunit 6 , and the poly ubiquitin gene, 3 ) the cathepsin proteolytic pathway including cathepsins D and L $[4,5]$. Total RNA, isolated from liver samples $(n=6 /$ group) using Trizol reagent, was further purified using an RNA clean-up kit according to the manufacturer's protocol (Zymo Research Corporation, Orange, CA). Two $\mu \mathrm{g}$ of each RNA sample were converted to cDNA using Super- 
Table 6: Differentially expressed genes of the immune response

\begin{tabular}{|c|c|c|c|c|c|}
\hline Symbol & Gene name & ACC.\# & p value & GO Term & $\begin{array}{l}\text { Fold } \\
\text { change }\end{array}$ \\
\hline $\mathrm{C3}$ & Complement component 3 & CB5I4355 & $2.5 \mathrm{E}-03$ & $\begin{array}{l}\text { inflammatory response - } \\
\text { GO:0006954 }\end{array}$ & -2.7 \\
\hline C5 & Complement component 5 & CB491279 & $2.8 \mathrm{E}-03$ & $\begin{array}{l}\text { inflammatory response - } \\
\text { GO:0006954 }\end{array}$ & -4.0 \\
\hline CFB & Complement factor B & CB511435 & $1.9 \mathrm{E}-02$ & $\begin{array}{l}\text { innate immune response - } \\
\text { GO:0045087 }\end{array}$ & -2.9 \\
\hline CFP & Complement factor properdin & CB498335 & $1.9 \mathrm{E}-03$ & $\begin{array}{l}\text { complement activation - } \\
\text { GO:0006957 }\end{array}$ & -4.1 \\
\hline \multirow[t]{2}{*}{ CLEC2B } & C-type lectin domain family 2 , member B & CB492852 & $8.4 \mathrm{E}-03$ & $\begin{array}{l}\text { antimicrobial humoral response - } \\
\text { GO:0019735 }\end{array}$ & -8.5 \\
\hline & similar to C-type lectin-like receptor 2 & CB496842 & 6.IE-04 & $\begin{array}{l}\text { antimicrobial humoral response - } \\
\text { GO:0019735 }\end{array}$ & -6.1 \\
\hline Hamp & Hepcidin antimicrobial peptide & CK991068 & I.6E-03 & iron homeostasis - GO:0006879 & -3.4 \\
\hline Tcrb-VI3 & T-cell receptor beta, variable 13 & $\overline{\mathrm{CB} 491795}$ & I.IE-04 & $\begin{array}{l}\text { T cell receptor signaling pathway - } \\
\text { GO:0050852 }\end{array}$ & 3.9 \\
\hline TRA@ & T cell receptor alpha locus & CB498619 & $2.2 \mathrm{E}-04$ & $\begin{array}{l}\text { cellular defense response - } \\
\text { GO:0006968 }\end{array}$ & 2.5 \\
\hline ACP5 & Acid phosphatase 5 , tartrate resistant & CB515428 & $2.8 \mathrm{E}-04$ & $\begin{array}{l}\text { acid phosphatase activity - } \\
\text { GO:0003993 }\end{array}$ & 5.7 \\
\hline VIPRI & Vasoactive intestinal peptide receptor I & CB511922 & 4.4E-04 & immune response - GO:0006955 & -3.9 \\
\hline BANFI & Barrier to autointegration factor I & CB505698 & I.0E-03 & response to virus - GO:00096I5 & -3.7 \\
\hline IGSF4C & Immunoglobulin superfamily, member $4 \mathrm{C}$ & $\overline{\mathrm{CA} 040781}$ & $6.6 \mathrm{E}-05$ & $\begin{array}{l}\text { immunoglobulin complex - } \\
\text { GO:0019814 }\end{array}$ & -3.3 \\
\hline LECTI & Leukocyte cell derived chemotaxin I & CA037891 & I.IE-03 & $\begin{array}{l}\text { proteoglycan metabolism - } \\
\text { GO:0006029 }\end{array}$ & -6.5 \\
\hline Edem I & $\begin{array}{l}\text { ER degradation enhancer, mannosidase alpha-like } \\
\text { I }\end{array}$ & $\underline{\mathrm{CA} 063288}$ & $3.4 \mathrm{E}-02$ & $\begin{array}{l}\text { response to unfolded protein- } \\
\text { GO:0006986 }\end{array}$ & 2.3 \\
\hline $\begin{array}{l}\text { SERPING } \\
\text { I }\end{array}$ & $\begin{array}{l}\text { Serpin peptidase inhibitor, clade } \mathrm{G} \text { ( } \mathrm{Cl} \text { inhibitor), } \\
\text { member I }\end{array}$ & CA037346 & $5.4 \mathrm{E}-03$ & $\begin{array}{l}\text { immune response-GO:0006955/ } \\
\text { blood }\end{array}$ & 1.5 \\
\hline
\end{tabular}

script II reverse transcriptase (Invitrogen, Carlsbad, CA). To ensure RNAs were free of genomic DNA, negative control cDNAs were prepared by reverse transcription reactions without adding the reverse transcriptase. Real time PCR primers were designed based on each gene sequence (Table 8) using Primer3 software [71]. Quantitative PCR was performed in duplicate for each cDNA sample on a Bio-Rad iCycler iQ Real-Time PCR Detection System using $\mathrm{iQ}^{\mathrm{TM}}$ SYBR $^{\oplus}$ Green Supermix (Bio-Rad, Hercules, CA) in 25$\mu \mathrm{l}$ reaction volumes containing $300 \mathrm{nM}$ of each primer and CDNA derived from $0.2 \mu \mathrm{g}$ of total RNA. The rainbow trout $\beta$-actin gene (its expression was not affected by starvation as shown by microarray analysis) was chosen as an endogenous control for normalization of the real time PCR analysis. Standard curves for each gene and the endogenous control were constructed using 10-fold serial dilutions of the corresponding plasmid. Standard curves were run on the same plate with the samples. Threshold lines were adjusted to intersect amplification lines in the linear portion of the amplification curve and cycles to threshold (Ct) were recorded. For each sample, the amount of target gene and endogenous reference was determined from the appropriate standard curve. The amount of the target gene was divided by the amount of reference gene to obtain a normalized target value. Mean differences in gene expression levels were determined by t-test and reported as relative fold changes.

\section{Calpain activity assay}

Calpain activity was measured using the calpain activity assay kit (Calbiochem, San Diego, CA) as described $[4,5,7]$. Briefly, liver tissues were homogenized in sample buffer. Cell lysates were incubated with the fluorogenic substrate Suc-LLVY AMC together with activation buffer. The release of the free AMC was measured at excitation and emission wavelengths of $370-\mathrm{nm}$ and 450-nm, respectively. The change in proteasome activity was normalized to sample protein concentration and expressed as relative fluorescence fold change.

\section{Proteasome activity assay}

Rainbow trout liver tissues were homogenized in lysis buffer (50 mM Tris pH 8.0, $0.1 \mathrm{mM}$ EDTA, $1.0 \mathrm{mM} 2 \beta$ mercaptoethanol) at $4{ }^{\circ} \mathrm{C}$, followed by centrifugation at $20,000 \mathrm{~g}$ for $10 \mathrm{~min}$, and the supernatant was retained. The concentration of proteins was determined using BSA as standard. Proteasome peptidase activity was measured using the $20 \mathrm{~S}$ proteasome assay kit as previously described $[4,5]$ and according to the manufacturer's protocol (Alexis Biochemicals, San Diego, CA). The activity 
Table 7: Differentially expressed genes of the proteolysis

\begin{tabular}{|c|c|c|c|c|c|}
\hline Symbol & Gene name & ACC.\# & p value & GO Term & $\begin{array}{l}\text { Fold } \\
\text { change }\end{array}$ \\
\hline Psmc6 & $\begin{array}{l}\text { Proteasome (prosome, macropain) } 26 \mathrm{~S} \\
\text { subunit, ATPase, } 6\end{array}$ & CB518083 & $4.3 \mathrm{E}-02$ & protein catabolism - GO:0030163 & -2.3 \\
\hline PSME2 & $\begin{array}{l}\text { Proteasome (prosome, macropain) } \\
\text { activator subunit } 2\end{array}$ & $\underline{\text { CB49|442 }}$ & $1.5 \mathrm{E}-02$ & protein catabolism - GO:0030163 & -5.7 \\
\hline Ubc & Ubiquitin C & CA048031 & $9.6 \mathrm{E}-04$ & $\begin{array}{l}\text { ubiquitin-dependent protein catabolism- } \\
\text { GO:00065II }\end{array}$ & -2.8 \\
\hline UCHL5 & Ubiquitin carboxyl-terminal hydrolase L5 & CA053740 & I.2E-02 & $\begin{array}{l}\text { ubiquitin-dependent protein catabolism- } \\
\text { GO:00065 II }\end{array}$ & -7.1 \\
\hline UBEIC & $\begin{array}{l}\text { Ubiquitin-activating enzyme EIC (UBA3 } \\
\text { homolog, yeast) }\end{array}$ & CA05I243 & $4.6 \mathrm{E}-02$ & proteolysis - GO:0006508 & -2.3 \\
\hline Ubb & Polyubiquitin & $\underline{\text { CB500037 }}$ & $6.5 \mathrm{E}-04$ & protein ubiquitination - GO:0016567 : & -4.4 \\
\hline $\mathrm{FBXO38}$ & F-box protein 38 & CB509947 & $4.2 \mathrm{E}-04$ & ubiquitin cycle - GO:00065I2 & -7.0 \\
\hline RBXI & Ring-box I & CA062272 & $8.6 \mathrm{E}-03$ & protein ubiquitination - GO:0016567 & -3.8 \\
\hline TRIM39 & Tripartite motif-containing 39 & CB514566 & $2.6 \mathrm{E}-02$ & protein ubiquitination - GO:0016567 & -2.0 \\
\hline PITRMI & Pitrilysin metallopeptidase I & CA050901 & $7.5 \mathrm{E}-03$ & metalloendopeptidase activity-GO:0004222 & -3.2 \\
\hline TIMP2 & TIMP metallopeptidase inhibitor 2 & CB49284I & $2.0 \mathrm{E}-02$ & enzyme inhibitor activity - GO:0004857 & -4.0 \\
\hline$A C Y I$ & Aminoacylase I & CA054045 & 2.IE-02 & amino acid metabolism - GO:0006520 & -2.1 \\
\hline ITIH5 & Inter-alpha (globulin) inhibitor $\mathrm{H} 5$ & CA039272 & $3.6 \mathrm{E}-02$ & hyaluronan metabolism - GO:0030212 & -2.8 \\
\hline Itih3 & Inter-alpha trypsin inhibitor, heavy chain 3 & CA037372 & $\mathrm{I} .8 \mathrm{E}-02$ & hyaluronan metabolism - GO:0030212 & -2.8 \\
\hline NUPRI & P8 protein (candidate of metastasis I) & CA043387 & $1.0 \mathrm{E}-02$ & induction of apoptosis - GO:0006917 & -2.9 \\
\hline SQSTMI & Sequestosome I & CB492474 & $\mathrm{I} .8 \mathrm{E}-04$ & apoptosis - GO:0006915 & -5.9 \\
\hline CASPIO & $\begin{array}{l}\text { Caspase } 10 \text {, apoptosis-related cysteine } \\
\text { peptidase }\end{array}$ & CB498395 & $7.4 \mathrm{E}-03$ & induction of apoptosis - GO:0006917 & -3.0 \\
\hline PDCD6 & Programmed cell death 6 & $\underline{\text { CB514639 }}$ & I.IE-03 & apoptosis - GO:0006915 & 3.1 \\
\hline Rilp & Rab interacting lysosomal protein & CB517236 & $2.2 \mathrm{E}-02$ & transport - GO:0006810 & -2.6 \\
\hline Edem I & $\begin{array}{l}\text { ER degradation enhancer, mannosidase } \\
\text { alpha-like I }\end{array}$ & CA063288 & $3.4 \mathrm{E}-02$ & response to unfolded protein-GO:0006986 & 2.3 \\
\hline
\end{tabular}

was measured using Suc-Leu-Leu-Val-Try-AMC as a substrate in a reaction mixture of $939 \mu \mathrm{l}$ of $1 \times$ reaction buffer, $10 \mu \mathrm{l}$ of $3 \%$ SDS, $1 \mu \mathrm{l}$ of $1000 \times$ substrate solution and 50 $\mu \mathrm{l}$ of sample. Release of the fluorogenic reagent AMC was determined at excitation and emission wavelengths of $380-\mathrm{nm}$ and $460-\mathrm{nm}$, respectively. The change in proteasome activity was normalized to sample protein concentration and expressed as relative fluorescence fold change.

\section{Cathepsins activity assay}

Cathepsin-L activity was measured using the synthetic substrate Z-Phe-Arg-AMC essentially according to $[4,5]$ as described in the manufacturer's protocol InnoZyme $^{\mathrm{TM}}$ Cathepsin-L Fluorogenic Activity Kit, Calbiochem, San Diego, CA). The release of the fluorogenic reagent AMC (7-amido-4-methylcoumarin) was determined by measuring fluorescence at excitation and emission wavelengths of 380-nm and 460-nm, respectively, in a Cary Eclipse fluorometer (Varian, Inc., Palo Alto, CA). Purified cathep$\sin -\mathrm{L}$ and cathepsin-L inhibitor (kit supplied) were used for positive and negative controls, respectively. Activity of cathepsin-D was measured as described previously $[4,5]$ using Bz-Arg-Gly-Phe-Phe-Pro-4MeOßNA, HCl (Calbiochem, San Diego, CA) as substrate. The reaction mixture contained $400 \mu \mathrm{l}$ of $50 \mathrm{mM}$ sodium acetate buffer, $\mathrm{pH}$ 4.0, $100 \mu \mathrm{l}$ of $200 \mu \mathrm{M}$ substrate solution and $40 \mu \mathrm{l}$ of sample.
The release of the fluorogenic reagent 4-MeOßNA was measured at excitation and emission wavelengths of 380$\mathrm{nm}$ and $425-\mathrm{nm}$, respectively. The change in activity was normalized to the sample protein concentrations and expressed as relative fluorescence fold change.

\section{Statistical analyses}

One-way analysis of variance (ANOVA) was performed on mean gene expression levels or enzyme activities using SigmaStat (version 3.11) software (Aspire Software International, Leesburg, VA). When one-way ANOVA showed significant effects, multiple mean comparisons were made using the Holm-Sidak method.

\section{Abbreviations}

NCCCWA, National Center for Cool and Cold Water Aquaculture; GEO, Gene Expression Omnibus; Capn1, Catalytic subunits of $\mu$-calpain; Capn2, Catalytic subunits of m-calpain; cpns, Calpain regulatory subunit; CAST-L; Calpastatin long isoform; CAST-S, Calpastatin short isoform; GADPH, Glyceraldehyde-3-phosphate dehydrogenase; C3, Complement component 3; ATP5J2, ATP synthase; ACP5, Acid phosphatase 5, tartrate resistant; FADS2, Fatty acid desaturase 2. 
Table 8: Primers used for real time RT-PCR analysis

\begin{tabular}{llll}
\hline Gene name & Forward primer & Reverse primer & $\begin{array}{l}\text { GenBank Acc. No.l } \\
\text { TIGR TC }\end{array}$ \\
\hline Capn I & & & AY573919 \\
Capn2 & 5-GCCAAAACATTGCCTGTTATCTTAG-3 & 5-ATAGGAGGCCGTATCAAAATTCC-3 & AY573920 \\
Cpns & 5-GCTGCCTTCAAATCTGCATGT-3 & 5-GGTTAAACACTGGAGCGTGTC-3 & AF482696 \\
CAST-S & 5-ATGACAGAGCAGCTGTCCAATC-3 & 5-TGTTGAAGCAACATCACTGCAA-3 & AY937408 \\
CAST-L & 5-ACGGCACCTTTCCTTTCCATTACCA-3 & 5-CGGGGGGAGCAGGAGACTTGGT-3 & AY937407 \\
Proteasome $\alpha$ 5 & 5-GGTGTAGCGCTTCTCTTTGG-3 & 5-ACTGGACAAAGGTGCCTGAT-3 & TIGR database TC78609 \\
Proteasome 33 & 5-CCCATGGTGACAGAGGACTT-3 & 5-TGTCTGGCTCCCAGAGAGAT-3 & TIGR database TC87448 \\
Proteasome N3 & 5-AAGTGAACGACAGCACCATTC-3 & 5-CCTCATCGATCACCATCTGTT-3 & CA386652 \\
Proteasome Regulatory 6-CCGACCTCAGAGAAAAGGTG-3 & 5-AGAAGAGGTACTGGCGGACA-3 & TIGR database TC8792I \\
Plyubiqitin & 5-CTGGAAGATGGTCGCACTCT-3 & 5-GATCTGCATACCTCCCCTCA-3 & AF36I365 \\
Cathepsin-D & 5-GCCTGTCATCACATTCAACCT-3 & 5-CCACTCAGGCAGATGGTCTTA-3 & U9032I \\
Cathepsin L & 5-TGAAGGAGAAGATGTGGATGG-3 & 5-TTCCTGTCTTTGGCCATGTAG-3 & AF358668 \\
GADPH & 5-CTGAACGACCACTTCGTCAA-3 & 5-TTACTCCTTGGTGGCCATGT-3 & CB49I826 \\
C3 & 5-CTAACGAGGGCAAGCTCAAC-3 & 5-GCCTCCAGAGTGAGAAGGTG-3 & CB5I4355 \\
ATP5J2 & 5-GGGCGGATAAAAAGGCTAAT-3 & 5-GCCATTTATTGCCTGAAGGA-3 & CB4936I2 \\
ACP5 & 5-CAAGCAGTTCGACTGGATCA-3 & 5-ACCAATGGACCACACAGGAT-3 & CB5I5428 \\
FADS2 & 5-GTCCGTGCTTTGTGTGAGAA-3 & 5-TCAGAGACCCGACAACATCA-3 & CB49466I \\
$\beta$ 3-Actin & 5-GCCGGCCGCGACCTCACAGACTAC-3 & 5-CGGCCGTGGTGGTGAAGCTGTAAC-3 & AJ438I58 \\
\hline
\end{tabular}

\section{Competing interests}

The author(s) declares that there are no competing interests.

\section{Authors' contributions}

MS was responsible for generating the gene expression and enzyme activity data, statistical analysis, and drafted the manuscript. JS co-authored the manuscript and was responsible for design of the starvation experiment and tissue collection. CR participated in coordination and provided some clones used in real time PCR analysis. JY was responsible for project development and is the corresponding author. All contributing authors reviewed and approved the final copy of this manuscript.

\section{Acknowledgements}

The authors thank Dr. P.B. Kenney for critical reading of the manuscript. This investigation was supported by Hatch Funds (Project No: 427) of the West Virginia Agricultural Experiment Station and USDA/ARS Cooperative Agreement No. 58-1930-5-537. It is published with the approval of the Director of the West Virginia Agriculture and Forestry Experiment Station as scientific paper No. 299I.

\section{References}

I. Carter CG, Houlihan DF: Protein synthesis. In Nitrogen Excretion Volume Vol. 20. Academic Press, edition. Issue Fish Physiol. Edited by: In: Walsh PJME. New York ; 2001 :pp. 3I-75.

2. Young VR, Steffee WP, Pencharz PB, Winterer JC, Scrimshaw NS: Total human body protein synthesis in relation to protein requirements at various ages. Nature 1975, 253:92-194.

3. Houlihan DF, Carter CG, McCarthy ID: Protein turnover in animals. In Nitrogen Metabolism and Excretion Edited by: In: Wright PJWPAE. CRC Press, Boca Raton; 1995:pp. I-32.

4. Salem M, Kenney PB, Rexroad E, Yao J: Molecular characterization of muscle atrophy and proteolysis associated with spawning in rainbow trout . Comp Biochem Physiol D Genomics Proteomics 2006, I(I):227-237.
5. Salem M, Levesque H, Moon TW, Rexroad CE, Yao J: Anabolic effects of feeding beta(2)-adrenergic agonists on rainbow trout muscle proteases and proteins. Comp Biochem Physiol $A$ Mol Integr Physiol 2006, I 44(2): I 45-I54.

6. Salem M, Nath J, Rexroad CE, Killefer J, Yao J: Identification and molecular characterization of the rainbow trout calpains (Capn I and Capn2): their expression in muscle wasting during starvation. Comp Biochem Physiol B Biochem Mol Biol 2005, I 40(I):63-7I.

7. Salem M, Yao J, Rexroad CE, Kenney PB, Semmens K, Killefer J, Nath $\mathrm{J}$ : Characterization of calpastatin gene in fish: its potential role in muscle growth and fillet quality. Comp Biochem Physiol $B$ Biochem Mol Biol 2005, I 4 I (4):488-497.

8. Van den Thillart G: Energy metabolism of swimming trout (Salmo gairdneri). Oxidation rates of palmitate, glucose, lactate, alanine, leucine and glutamate. J Comp Physiol, B 1986 , I56:5II -520.

9. Peragon J, Barroso JB, Garcia-Salguero L, Aranda F, de la Higuera M, Lupianez JA: Selective changes in the protein-turnover rates and nature of growth induced in trout liver by long-term starvation followed by re-feeding. Mol Cell Biochem I999, 20 I (I2): $1-10$.

10. Loughna PT, Goldspink G: The effects of starvation upon protein turnover in red and white myotomal muscle of rainbow trout, Salmo gairdneri Richardson. Journal of Fish Biology 1984, Volume 25 (2):223

II. Tripathi G, Verma P: Starvation-induced impairment of metabolism in a freshwater catfish. Z Naturforsch (C) 2003, 58(56):446-45I.

12. Melese $T, X u e ~ Z:$ The nucleolus: an organelle formed by the act of building a ribosome. Curr Opin Cell Biol I995, 7(3):3 I9-324.

13. Cukras AR, Southworth DR, Brunelle JL, Culver GM, Green R: Ribosomal proteins $S I 2$ and SI3 function as control elements for translocation of the mRNA:tRNA complex. Mol Cell 2003, I2(2):32I-328.

14. Voet D, Voet JG, Pratt CW: Fundamentals of Biochemistry. USA , John Wiley \& Sons, Inc; 2006.

15. Harding HP, Zhang Y, Zeng H, Novoa I, Lu PD, Calfon M, Sadri N, Yun C, Popko B, Paules R, Stojdl DF, Bell JC, Hettmann T, Leiden JM, Ron $D$ : An integrated stress response regulates amino acid metabolism and resistance to oxidative stress. Mol Cell 2003, II(3):619-633.

16. Jurss $K$, Junghahn I, Bastrop R: The role of elongation factors in protein synthesis rate variation in white teleost muscle. J Comp Physiol (B) 1992, I 62(4):345-350. 
17. Zempleni J: Uptake, localization, and noncarboxylase roles of biotin. Annu Rev Nutr 2005, 25: I 75-196.

18. Stephenson K: Sec-dependent protein translocation across biological membranes: evolutionary conservation of an essential protein transport pathway (review). Mol Membr Biol 2005, 22(I-2): 17-28.

19. Pace DA, Manahan DT: Fixed metabolic costs for highly variable rates of protein synthesis in sea urchin embryos and larvae. J Exp Biol 2006, 209(Pt I): I58-170.

20. Fraser KP, Houlihan DF, Lutz PL, Leone-Kabler S, Manuel L, Brechin JG: Complete suppression of protein synthesis during anoxia with no post-anoxia protein synthesis debt in the red-eared slider turtle Trachemys scripta elegans. J Exp Biol 200I, 204(Pt 24):4353-4360.

2I. Smith RW, Houlihan DF, Nilsson GE, Brechin JG: Tissue-specific changes in protein synthesis rates in vivo during anoxia in crucian carp. Am J Physiol 1996, 27 I (4 Pt 2):R897-904.

22. Model K, Meisinger C, Prinz T, Wiedemann N, Truscott KN, Pfanner N, Ryan MT: Multistep assembly of the protein import channel of the mitochondrial outer membrane. Nat Struct Biol 200I, 8(4):36I-370.

23. Moon TW, Foster GD: Tissue carbohydrate metabolism, gluconeogenesis and hormonal and environmental influences. In Biochemistry and Molecular Biology of Fishes Edited by: In: (Hochachka and Mommsen . Amsterdam , Elsevier Science; 1995:pp. 65-100.

24. Wilson RP: Utilisation of dietary carbohydrate by fish. In Aquaculture Volume 124. Edited by: In: (Hochachka and Mommsen, eds). Amsterdam, , Elsevier Science Publisher.; 1994:67-80.

25. Morata P, Vargas AM, Sanchez-Medina F, Garcia M, Cardenete G, Zamora S: Evolution of gluconeogenic enzyme activities during starvation in liver and kidney of the rainbow trout (Salmo gairdneri). Comp Biochem Physiol (B) 1982, 7 I (I):65-70.

26. Foster GD, Moon TW: Hypometabolism with fasting in the yellow perch (Perca flavescens): a study of enzymes, hepatocyte metabolism, and tissue size. Physiological Zoology I991, 64, :259-275.

27. Guderley H, Lapointe D, Bedard M, Dutil JD: Metabolic priorities during starvation: enzyme sparing in liver and white muscle of Atlantic cod, Gadus morhua L. Comp Biochem Physiol A Mol Integr Physiol 2003, 135(2):347-356.

28. Storey KB: Oxidative stress: animal adaptations in nature. Braz J Med Biol Res 1996, 29(I 2): I7| 5-1733.

29. Recalcati S, Tacchini L, Alberghini A, Conte D, Cairo G: Oxidative stress-mediated down-regulation of rat hydroxyacid oxidase I, a liver-specific peroxisomal enzyme. Hepatology 2003, 38(5): $1159-1166$

30. Jimenez A, Pelto-Huikko M, Gustafsson JA, Miranda-Vizuete A: Characterization of human thioredoxin-like-I: potential involvement in the cellular response against glucose deprivation. FEBS Lett 2006, 580(3):960-967.

31. Watanabe T: Lipid nutrition in fish. Comp Biochem Physiol 1982 73B:3 - 15

32. Havel RJ: Lipoproteins and lipid transport. Adv Exp Med Biol 1975, 63:37-59.

33. Liu RZ, Denovan-Wright EM, Wright JM: Structure, linkage mapping and expression of the heart-type fatty acid-binding protein gene (fabp3 ) from zebrafish (Danio rerio). Eur J Biochem 2003, 270(I 5):3223-3234.

34. Vayda ME, Londraville RL, Cashon RE, Costello L, Sidell BD: Two distinct types of fatty acid-binding protein are expressed in heart ventricle of Antarctic teleost fishes. Biochem ] 1998, 330 ( Pt I):375-382.

35. Jezierska B, Hazel JR, Gerking SD: Lipid mobilization during starvation in the rainbow trout, Salmo gairdneri Richardson, with attention to fatty acids. J Fish Biol 1982, 21:681-692.

36. Rasmussen RS, Ostenfeld TH, Rénsholdt B, Mclean E: Manipulation of end-product quality of rainbow trout with finishing diets. Aquaculture Nutrition 2000 , 6: 17-23.

37. Salem M, Kenney B, Rexroad CE, Yao J: Microarray gene expression analysis in atrophying rainbow trout muscle: $A$ unique non-mammalian muscle degradation model. Physiol Genomics 2006, 28:33-45.

38. Kaestner KH, Ntambi JM, Kelly TJ Jr., Lane MD: Differentiationinduced gene expression in 3T3-LI preadipocytes. A second differentially expressed gene encoding stearoyl-CoA desaturase. J Biol Chem 1989, 264(25): 14755-I476I.
39. Smith GG, Thompson PA, Ritar AJ, Dunstan GA: Effects of starvation and feeding on the fatty acid profiles of Stage I phyllosoma of the spiny lobster, Jasus edwardsii. Aquaculture Research 2003, $34: 419$

40. Mead JF, Fulco AJ: The unsatureated and polyunsaturated fatty acids in health and disease. Springfield, Illinois, Thomas; 1976.

4I. Quinkler M, Bujalska IJ, Tomlinson JW, Smith DM, Stewart PM Depot-specific prostaglandin synthesis in human adipose tissue: a novel possible mechanism of adipogenesis. Gene 2006, 380(2): $|37-| 43$.

42. Sztalryd C, Bell M, Lu X, Mertz P, Hickenbottom S, Chang BH, Chan $L$, Kimmel AR, Londos C: Functional compensation for adipose differentiation-related protein (ADFP) by Tip47 in an ADFP null embryonic cell line. J Biol Chem 2006, 28 I (45):3434|-34348.

43. Wicher KB, Fries E: Haptoglobin, a hemoglobin-binding plasma protein, is present in bony fish and mammals but not in frog and chicken. Proc Natl Acad Sci U S A 2006, I03(I I):4I68-4I73.

44. Kawakoshi A, Hyodo S, Nozaki M, Takei Y: Identification of a natriuretic peptide (NP) in cyclostomes (lamprey and hagfish): CNP-4 is the ancestral gene of the NP family. Gen Comp Endocrinol 2006, I 48(I):4I-47.

45. Chaves-Pozo E, Mulero V, Meseguer J, Garcia Ayala A: Professional phagocytic granulocytes of the bony fish gilthead seabream display functional adaptation to testicular microenvironment. J Leukoc Biol 2005, 78(2):345-35I.

46. Bayne C], Gerwick L, Fujiki K, Nakao M, Yano T: Immune-relevant (including acute phase) genes identified in the livers of rainbow trout, Oncorhynchus mykiss, by means of suppression subtractive hybridization. Dev Comp Immunol 200I, 25(3):205-217.

47. Ewart KV, Belanger JC, Williams J, Karakach T, Penny S, Tsoi SC Richards RC, Douglas SE: Identification of genes differentially expressed in Atlantic salmon (Salmo salar) in response to infection by Aeromonas salmonicida using cDNA microarray technology. Dev Comp Immunol 2005, 29(4):333-347.

48. Lauth X, Babon JJ, Stannard JA, Singh S, Nizet V, Carlberg JM, Ostland VE, Pennington MW, Norton RS, Westerman ME: Bass hepcidin synthesis, solution structure, antimicrobial activities and synergism, and in vivo hepatic response to bacterial infections. I Biol Chem 2005, 280(1 0):9272-9282.

49. Bayne CJ, Gerwick L: The acute phase response and innate immunity of fish. Dev Comp Immunol 200I, 25(8-9):725-743.

50. Courselaud B, Pigeon C, Inoue Y, Inoue J, Gonzalez F], Leroyer P, Gilot D, Boudjema K, Guguen-Guillouzo C, Brissot P, Loreal O, llyin G: C/EBPalpha regulates hepatic transcription of hepcidin, an antimicrobial peptide and regulator of iron metabolism. Cross-talk between C/EBP pathway and iron metabolism. Biol Chem 2002, 277(43):4 I |63-4II 70.

5I. Rise ML, Jones SR, Brown GD, von Schalburg KR, Davidson WS, Koop BF: Microarray analyses identify molecular biomarkers of Atlantic salmon macrophage and hematopoietic kidney response to Piscirickettsia salmonis infection. Physiol Genomics 2004, 20(I):21-35

52. Raisanen SR, Alatalo SL, Ylipahkala H, Halleen JM, Cassady Al, Hume DA, Vaananen HK: Macrophages overexpressing tartrateresistant acid phosphatase show altered profile of free radical production and enhanced capacity of bacterial killing. Biochem Biophys Res Commun 2005, 33 I ( I): I 20-I 26.

53. Venketaraman V, Dayaram YK, Amin AG, Ngo R, Green RM, Talaue MT, Mann J, Connell ND: Role of glutathione in macrophage control of mycobacteria. Infect Immun 2003, 7 I (4): | 864- |87I.

54. Goldstone HM, Stegeman JJ: A revised evolutionary history of the CYPIA subfamily: gene duplication, gene conversion, and positive selection. I Mol Evol 2006, 62(6):708-717.

55. NCBI Gene Expression Omnibus [http://www.ncbi.nlm.nih.gov/ $\mathrm{geo} /]$

56. Du M, Zhu MJ, Means WJ, Hess BW, Ford SP: Effect of nutrient restriction on calpain and calpastatin content of skeletal muscle from cows and fetuses. J Anim Sci 2004, 82(9):254|-2547.

57. Pringle TD, Calkins CR, Koohmaraie M, Jones SJ: Effects over time of feeding a beta-adrenergic agonist to wether lambs on animal performance, muscle growth, endogenous muscle proteinase activities, and meat tenderness. I Anim Sci 1993 , $7 I(3): 636-644$.

58. Morgan JB, Wheeler TL, Koohmaraie M, Crouse JD, Savell JW: Effect of castration on myofibrillar protein turnover, endogenous 
proteinase activities, and muscle growth in bovine skeletal muscle. J Anim Sci 1993, 7 I(2):408-4I4.

59. Tidball JG, Spencer MJ: Expression of a calpastatin transgene slows muscle wasting and obviates changes in myosin isoform expression during murine muscle disuse. J Physiol 2002, 545(Pt 3):819-828.

60. Purintrapiban J, Wang MC, Forsberg NE: Degradation of sarcomeric and cytoskeletal proteins in cultured skeletal muscle cells. Comp Biochem Physiol B Biochem Mol Biol 2003, I 36(3):393-40I.

61. Martin SA, Blaney S, Bowman AS, Houlihan DF: Ubiquitin-proteasome-dependent proteolysis in rainbow trout (Oncorhynchus mykiss): effect of food deprivation. Pflugers Arch 2002, 445(2):257-266.

62. Dobly A, Martin SA, Blaney SC, Houlihan DF: Protein growth rate in rainbow trout (Oncorhynchus mykiss) is negatively correlated to liver 205 proteasome activity. Comp Biochem Physiol A Mol Integr Physiol 2004, I 37(I):75-85.

63. Mommsen TP: Salmon spawning migration and muscle protein metabolism: the August Krogh principle at work. Comp Biochem Physiol B Biochem Mol Biol 2004, I 39(3):383-400.

64. Silverstein JT, Rexroad CEIII, King T: Genetic variation measured by microsatellites among three strains of domesticated rainbow trout. Aquaculture Research 2004, 35:40-48.

65. von Schalburg KR, Rise ML, Cooper GA, Brown GD, Gibbs AR, Nelson CC, Davidson WS, Koop BF: Fish and chips: various methodologies demonstrate utility of a 16,006-gene salmonid microarray. BMC Genomics 2005, 6: 126.

66. Consortium for Genomic Research on All Salmon Project [http://web.uvic.ca/cbr/grasp/array.html]

67. Yao J, Ren X, Ireland JJ, Coussens PM, Smith TP, Smith GW: Generation of a bovine oocyte cDNA library and microarray: resources for identification of genes important for follicular development and early embryogenesis. Physiol Genomics 2004, 19(1):84-92

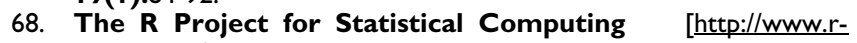
project.org/]

69. Bioconductor [http://www.bioconductor.org/]

70. GenePix Auto Processor [http://darwin.biochem.okstate.edu/ gрap3/]

71. Primer

primer3 www.cgi] [http://frodo.wi.mit.edu/cgi-bin/primer3/
Publish with Biomed Central and every scientist can read your work free of charge

"BioMed Central will be the most significant development for disseminating the results of biomedical research in our lifetime. "

Sir Paul Nurse, Cancer Research UK

Your research papers will be:

- available free of charge to the entire biomedical community

- peer reviewed and published immediately upon acceptance

- cited in PubMed and archived on PubMed Central

- yours - you keep the copyright

Submit your manuscript here:

http://www.biomedcentral.com/info/publishing_adv.asp
BioMedcentral 